\title{
The 2004 Tsunami in Aceh and Southern Thailand: Coastal Ecosystem Services, Damages and Resilience
}

\author{
Roland Cochard \\ Natural Resources Management, School of Environment and Resource Development, \\ Asian Institute of Technology, Pathumthani, \\ Thailand
}

\section{Introduction}

The expression of a "black swan" became popular during the 2008 economic crisis by a bestselling book by Nicolas Taleb (2007); today a "black swan" is an allegory to describe an event which is deemed highly improbable (unthinkable within experienced reality), yet can cause massive consequences when it actually occurs. Originally, in the Old World, a "black swan" was the quintessential "rare bird on Earth", and only with the discovery of black swans in the $17^{\text {th }}$ century on Australia the conviction that all swans must be white was overturned. In 2010 the allegory, however, reached a new dimension of pictographic realism as the largest-ever oil pest was (and still is) turning thousands of sea-birds into tar-balls in the Gulf of Mexico. This oil pest was caused by the technical limitations to provide a quick fix to a leak from an oil well that is more than a kilometer below sea level (The Economist 2010). The oil pest is now magnitudes larger than anything seen before; it will have a lasting impact on the region's coastal ecosystems for decades to come. It is a stark reminder of today's exposures and fragilities of the coastal zone and the human technical limitations, economic dependencies and short-sighted priorities in dealing with risks.

The great "black swan" of the year 2004 was of natural origin and of an even more sudden catastrophic nature. During only one day (26 December) a huge tsunami killed up to about 300 '000 people (two thirds thereof in the Indonesian Province of Aceh), sending physical and psychological shock waves around the planet. In addition to being highly fatal, the event caused massive destruction of housing and infrastructure and the displacement of over 10 million people. Compared to other disasters of similar magnitude, responsiveness of the international community was fast and aid donations were copious (more than 10 billion US\$; Wikipedia 2010). In the jargon of some NGO workers and consultants the "second wave" soon came to mean the initial flow of aid money; however, necessities and the efficiency and distribution of aid differed significantly between regions, and the attention of the donor community soon turned away to other priorities.

After the disaster, many NGO's involved in conservation activities were quick to find explanations: according to them the impacts of the giant waves were much increased where coastal ecosystems had been destroyed or damaged, e.g. in areas where mangroves had been replaced by shrimp farms. "Building back better" was a guiding theme for 
reconstruction; it included the idea of restoring coastal ecosystems - in particular mangroves and beach forests - for use as bio-shields against future tsunamis. While the scientific evidence for a life-protection role of mangroves and other ecosystems still fails to be very convincing (cf. Cochard et al. 2008, Feagin et al. 2010, Bhalla 2007), mangroves and other coastal ecosystems provide a multitude of socially and economically relevant environmental services; these services may be of particular importance during and after disaster events, contributing to socio-economic robustness and resilience of coastal communities (Adger et al. 2005, Alongi 2008, Cochard et al. 2008). According to UNEPWCMC (2006, p. 4) the tsunami was a "wake-up call for the global community, dramatically drawing attention to the vulnerability of coastal ecosystems and the dangers of undermining the services they provide to humankind". This call has been heeded by donors around the world, and since the catastrophe several international and state-funded programs have taken on the task to rehabilitate devastated ecosystems along the affected coastlines (cf. Feagin et al. 2010, Stone 2006, Wibisono and Suryadiputra 2006).

How successful have these programs been? Were these programs adequately planned and implemented? Were they at all necessary? In Aceh many attempts made at restoring coastal ecosystems were indeed unnecessarily wasteful, and many expensive schemes to stabilise the coastline were implemented without proper post-disaster surveying. During a visit to Aceh between 26 July and 2 August 2006, I observed many hectares of replanted mangrove seedlings around Banda Aceh and along parts of the tsunami-affected southern coastline. Most of these seedlings were already dead at the time of the visit, and freshly planted seedlings showed signs of rapid weakening with clearly no prospect for survival beyond the seedling stage (Fig. 1a). Similar observations near Banda Aceh were still made in 2008 by B. McAdoo (pers. comm.; Fig. 1e); observations are also confirmed by a consultancy report (Wibisono and Suryadiputra 2006). This contrasts with observations I made in 2006 of vigorous natural growth of the mangrove palm Nypa fruticans and the mangrove fern Acrostichum aureum in parts of some of the devastated swamps or of nearby periodically flooded areas, e.g. former paddy fields (Fig. 1c). It also contrasts with apparently largely successful mangrove replantation schemes along the affected coastlines in Southern Thailand, as I had observed during a visit to the affected Andaman Sea coastlines between 23 and 26 March 2006.

A "black swan" may be a positive or a negative event; what is most important, however, is the reaction to it (Taleb 2007). Did human communities really "take advantage" from the tsunami (respectively the "the second wave") to "build back better"? What has been learnt from this event? It appears that few restoration programs so far implemented have been accompanied or assessed by independent professionals. There have been some self-critical evaluations by international agencies (e.g. Wibisono and Suryadiputra 2006), but hardly anything is written about the success or failure of restoration programs in the scientific academic literature. This despite the fact that restoration programs would offer major opportunities for innovative scientific studies and progress. At the same time, the efficacy of such aid and development programs could decidedly be improved by implementing recursive learning schemes that strategically use scientific assessments as a means to develop "better" (i.e. more appropriate at any given point in time) management actions (cf. Gross et al. 2005).

In a previous article (Cochard et al. 2008) we outlined some concepts of risk assessment and management. We concentrated mainly on aspects of vulnerability and the effects of direct fast and catastrophic sea wave hazards, in particular the tsunami. In this article the scope is 


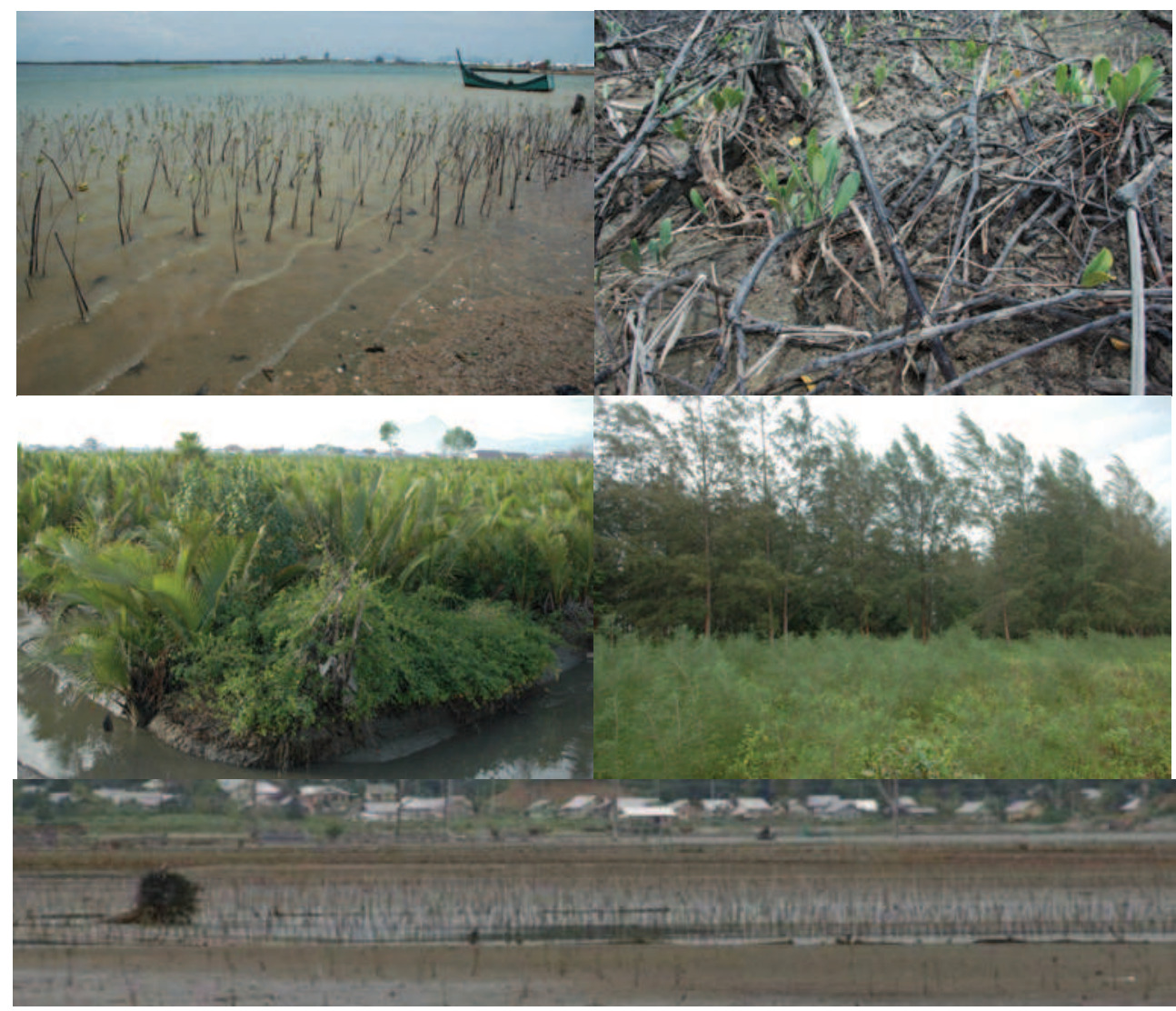

Fig. 1. (a) Root resprouting in a broken Rhizophora apiculata stand at Thale Nok, Thai Andaman coastline. (b) Rhizophora seedlings planted along the rims of rehabilitated tambak ponds close to Banda Aceh. Most of the seedlings were already dead. No successful seedling establishment was seen around Banda Aceh in July 2006 except for (c) vigourous growth ( $3 \mathrm{~m}$ in height) of mangrove palms, Nypa fruticans, in an area close to the mouth of the Aceh River. (d) In areas where beaches were not completely eroded, natural and aided regrowth of Casuarina trees was successful in Aceh as well as in Thailand. Here a regenerating stand on Ko Kho Khao, Thai Andaman coastline. Pictures: R.Cochard, July 2006. (e) Dead Rhizophora seedlings on a mudflat close to Banda Aceh in January 2008 (picture source: Dr. B. McAdoo).

further extended to aspects of risk robustness and resilience. Attention is drawn to several issues of importance in regard to the development needs of greenbelt restoration schemes. Information is drawn from scientific literature, reports of international organizations and NGO's, and some own experience in the field. Visits to the tsunami-affected coastlines of Aceh Province in Indonesia were conducted between 23 July and 2 August 2006 (Banda Aceh to Meulaboh, including Pulau Weh) and to the Andaman Sea of Thailand between 23 and 26 March 2006 (Thai coastline, Phuket to Ranong). Many of my personal observations, particularly regarding the impacts of the tsunami on coastal vegetation, form thereby one pillar of this article. 
The aim of this article was 1.) to provide a short overview over the functions, services and valuation of coastal ecosystems, specifically focusing on resilience aspects in the aftermath of tsunamis, 2.) to review the actual impacts and conditions of coastal ecosystems after the 2004 tsunami, 3.) to review the longer-term anthropogenic impacts on coastal ecosystems, and 4.) to review indirect damages and changes within impacted ecosystems, and 5.) discuss associated problems of ecosystem rehabilitation, respectively natural regeneration.

\section{The utility of coastal ecosystems}

\subsection{The utility of coastal ecosystems as a protection against tsunamis}

Following the 2004 tsunami the state of the environment along affected coastlines and the tsunami impacts have been assessed by various international, governmental and private missions (cf. Cochard et al. 2008). A part of the concern about the ecosystems was fuelled by the assumption that intact ecosystems had provided significant disaster mitigation services during the tsunami, and that the vulnerability of communities along the affected coastlines was therefore significantly heightened if ecosystems had been destroyed or been degraded during the catastrophe. If this was the case, then efforts at reconstruction would also have been put at increased risk of falling victim to a subsequent tsunami.

Up to this date relatively few informative studies have been published as to what degree intact coastal ecosystems may have provided protection. Primarily based on anecdotal accounts, many reports by aid organisations and environmental NGOs as well as some scientific publications have initially emphasised the positive protection function provided by coastal ecosystems during the disaster, in particular mangroves and coral reefs (see listing in Cochard et al. 2008). However later studies, reports and recommendations, based on more analytical assessments, have cautioned against many as yet unsubstantiated claims (see Feagin et al. 2010, Cochard et al. 2008, Chatenoux \& Peduzzi 2007, Kerr et al. 2006, Kerr \& Baird 2007).

According to an analysis by Chatenoux \& Peduzzi (2007), the force and impact of the tsunami mainly depended on the distance to the tsunami source and on coastal topography (particularly near-shore coastal bathymetry). Chatenoux \& Peduzzi's (2007) study may, however, contain some weaknesses in that it used multivariate regression statistical methods that did not account for spatial auto-correlation of the data points; this may partly explain why coral reefs appeared to have a positive effect on the tsunami impacts. Regarding the multivariate and spatially interdependent nature of the problem, the relative protection afforded by coral reefs and mangroves is difficult to elaborate and quantify in general terms. In addition, in many cases evaluations appear to contain a certain researcher's bias: remarkably few articles have so far considered that ecosystems can also have the potential to increase tsunami hazards in certain locations, for example by channelling and focussing water flows, or by increasing the impact force by contributing to flow debris (Cochard et al. 2008). Evaluating and quantifying tsunami risk at any coastal location requires elaborate multivariate spatial modelling incorporating detailed hydraulic baseline assessments; many of the parameters needed for models are as yet insufficiently understood (Cochard et al. 2008).

At the present stage the utility of coastal ecosystems as a tsunami buffer is, therefore, still controversial. It is probably minor as compared to other services provided by these ecosystems; more elaborate research projects would be needed to provide more conclusive scientific answers. Nevertheless, various environmental agencies and NGOs have used the 
tsunami disaster in order to pressure for greener agendas along the affected coasts, whereby the argument of any tsunami protection may have served for different ends than direct investment in risk management. Whether such observation is testimony to a sort of "machiavellism" by exponents of environmental agencies, as has been stated by some observers (e.g. Baird 2006), is a matter of perspective. Interestingly enough, however, the new TEEB (2010) report still cites Kathiresan and Rajendran (2005) as a source when referring to tsunamis, rather than referring to more substantial and objective, newer literature - and this despite the fact that several authorities on the subject had previously highlighted the scientific shortcomings of that particular paper!

\subsection{The role of coastal ecosystems regarding other risk mitigation services}

As to what measure investment in environmental reconstruction may influence the risk of future generations living along the coastlines does not merely depend on aspects of direct tsunami hazard mitigation. More holistic approaches to 'risk' also include the concept of "resilience", respectively "robustness" (cf. Adger et al. 2005). If conducted in a proper way, coastal restoration projects may not only mitigate the risks of further coastal erosion and decline of livelihood resources; such projects may also play important social and educational functions, implanting resilience to future generations (cf. Pomeroy et al. 2006). Considering ecosystem functions there are various valid reasons other than the tsunami per se that may justify investment in the rehabilitation and sustainable management of coastal resources.

Firstly, in addition to a potential protection against tsunamis, coastal ecosystems, such as coral reefs, seagrass beds, mangroves and vegetated sand dunes, can provide protection against normal and extreme wind-driven waves (including cyclonic storm surges), coastal erosion, and inland saltwater intrusion (Cochard et al. 2008, Das \& Vincent 2009). Areas where coastal ecosystems had been destroyed can, therefore, be expected to be exposed to a higher degree to such more common sea-borne hazards. In Aceh in particular, the heavily affected coastlines have been unstable after the tsunami. Coastline changes have been difficult to predict, hampering proper and efficient planning of housing and infrastructure reconstruction in several locations near the coast (O. Nieuwenhuis, pers. comm.). Major reshaping of the coastlines occurred mainly during several days of stormy weather, for example, during a modest rainstorm with high wind speeds $\left(\sim 50 \mathrm{~km} \mathrm{~h}^{-1}\right)$ that occurred in Banda Aceh on 9 May 2005 (Meilianda et al. 2006). Around 15-17 May 2007 disaster struck as waves up to $5 \mathrm{~m}$ high (produced by a uncommon constellation) destroyed hundreds of houses and displaced thousands of people along the southern coasts of Indonesia from Bali up to northern Sumatra; in Aceh Barat about 375 houses had to be abandoned by residents in five villages (AlertNet 2010). Losses of mangroves and other vegetation can also lead to significant increases of coastal erosion. According to a study by Thampanya et al. (2006) net annual land losses of $0.25 \mathrm{~km}^{2}$ were measured between 1966 and 1998 along the Andaman coastline; along the western Gulf of Thailand coastline, where about $90 \%$ of the former mangrove forests had been destroyed, annual erosion rates were even three times higher $\left(0.91 \mathrm{~km}^{2}\right)$.

Secondly, coastal ecosystems also provide mitigating functions against land-borne hazards. Forested coastal swamps, for example, can act as overflow areas in flooding periods. Especially peat swamp forests which occur in western coastal Aceh have a great potential to absorb and store floodwaters, and mitigate fast flash flood hazards. Strong rainfall events in catchments (increasingly affected by up-stream deforestation), for example, caused flash 
floods on 22 December 2006 at Lhokseumawe and in North Aceh, displacing about 170'000 and killing $>70$ people in 160 villages (ReliefWeb 2010). Swamplands, and to some degree seagrass beds, furthermore act as a filter for sediments and nutrients in domestic wastewater, thereby protecting the marine environment - in particular sensible ecosystems such as coral reefs, which in turn are important for fisheries and coastal protection (Wong et al. 1995, Chu et al. 1998, Cochard et al. 2008).

Thirdly, many other, primarily economic services are provided by coastal ecosystems (Adger et al. 2005). Mangrove forests provide shelter and nutrients, and are therefore important feeding, spawning and nursery grounds for fishes, crustaceans and other marine life (Ikejima et al. 2003, Chong et al. 1990). The richness of fisheries resources along the coastlines of some Asian countries has been attributed to the presence of mangroves (Amarasinghe et al. 2002, Islam and Haque 2004, Islam and Wahab 2005). Equally, research has found that fish catch is higher in reefs which are close to mangrove areas, whereby reefs and mangroves are often linked by sea grass beds (Dorenbosch et al. 2004, Mumby et al. 2004); some economically important species also depend on sea grass beds for some stage of their life cycle (Chou 1994). The value of South East Asia's fisheries in coral reefs alone is estimated to be US\$ 2.4 billion per year; in Indonesia economic benefits from reefs including tourism are estimated to be US\$ 1.6 billion per year (Burke et al. 2002). Commercial annual fish harvests in Indonesian mangroves have been estimated at up to $\$ 60^{\prime} 000 \mathrm{~km}^{-2}$ (Bann in UNEP-WCMC 2006). Other commercial products from coastal ecosystems include timber, pharmaceuticals, honey, and other plant and animal products; coral reefs in particular are attractive for tourism (UNEP-WCMC 2006). In Aceh, mangrove species are used for roof thatch (the mangrove palm, Nypa fruticans and Pandanus spp.), fuelwood, charcoal production and building materials for housing and boat construction (Rhizophora spp., Sonneratia spp., Avicennia spp., Ceriops tagal), and the production of honey (mainly Avicennia spp.). Furthermore, the fruits of $N$. fruticans and Sonneratia alba can be consumed for food; the fruit of $N$. fruticans also has potential as a source for biofuel production (Kanagaratnam et al. 2006). Estimations from the literature of the use value of mangroves range from less than 3000 US $\$$ ha $^{-1} \mathrm{y}^{-1}$ to more than $60^{\prime} 000$ US\$ ha-1 $\mathrm{y}^{-1}$ (e.g. Sathirathai and Barbier 2001, Iftekhar 2008, Cabrera et al. 1998, Costanza et al. 1997).

\section{Direct impacts of the 2004 tsunami on coastal ecosystems}

Ecosystems weakened by a catastrophe such as a tsunami are likely to be more vulnerable to a subsequent catastrophe, provided there was no time for sufficient recovery. Investments in environmental restoration may, therefore, be a sensible strategy to fasten regeneration processes, thereby enhancing overall robustness and decreasing the vulnerability to subsequent hazards. The question must, however, be raised about what was actually the impact of the 2004 tsunami. If impacts were minor and natural regeneration is fast, such investments may not improve the situation; rather they may represent a waste of resources that could be used for other more tangible efforts to reduce various risks (e.g. early warning systems in the case of tsunamis; cf. Kerr \& Baird 2007, Cochard et al. 2008).

Cochard et al. (2008) summarised and described the major coastal ecosystems of the region. Here an overall account is presented of the damages assessed in Aceh and on the Thai Andaman coast following the 2004 tsunami. References and some data are summarised in Table 1. Despite initial fears of an immense impact, some reports indicated that many ecosystems were surprisingly little affected in many areas, except in coastal areas of Aceh 
(Banda Aceh, west coast and some forelying islands), which were directly exposed and close to the epicentre. In Aceh in particular, the database is, however, highly inadequate; most of the figures found in reports were based on rough assumptions.

\begin{tabular}{|c|c|c|c|c|c|c|}
\hline \multirow{3}{*}{$\begin{array}{c}\text { Coastal } \\
\text { ecosystem }\end{array}$} & \multicolumn{3}{|c|}{ Aceh Province coastline } & \multicolumn{3}{|c|}{ Thai Andaman coast } \\
\hline & \multirow{2}{*}{$\begin{array}{l}\text { total area } \\
\text { or } \\
\text { coastline } \\
\text { length }\end{array}$} & \multicolumn{2}{|c|}{$\begin{array}{c}\text { affected }{ }^{\alpha}, \text { heavily } \\
\text { affected }{ }^{\eta} \text {, destroyed } \delta\end{array}$} & \multirow{2}{*}{$\begin{array}{l}\text { total area } \\
\text { or } \\
\text { coastline } \\
\text { length }\end{array}$} & \multicolumn{2}{|c|}{$\begin{array}{c}\text { affected } \alpha, \text { heavily } \\
\text { affected }{ }^{\eta}, \text { destroyed } \delta\end{array}$} \\
\hline & & hectares & percent & & hectares & percent \\
\hline Coral reefs & 97250 ha? & $\begin{array}{c}\sim 19000 \text { ha }{ }^{\alpha} \\
?\end{array}$ & $\sim 30 \%$ a? & 7900 ha* & $\begin{array}{l}\sim 1420 \text { ha }^{\eta} \\
\sim 4760 \text { ha }^{\text {a }}\end{array}$ & $\begin{array}{l}\sim 18 \%^{\eta} \\
\sim 60.3 \% \text { a }\end{array}$ \\
\hline $\begin{array}{l}\text { Sea grass } \\
\text { beds }\end{array}$ & $\sim 600$ ha? & 300 ha a ?? & $\sim 50 \%$ a ?? & 7937 ha & $\begin{array}{l}120 \text { ha }^{\delta} \\
278 \text { ha }^{\alpha}\end{array}$ & $\begin{array}{l}1.5 \% \text { } \delta \\
3.5 \% \text { a }\end{array}$ \\
\hline $\begin{array}{l}\text { Mangrove } \\
\text { forest }\end{array}$ & $341^{\prime} 000$ ha & $\sim 80^{\prime} 000$ ha $?$ & $\sim 20 \% \delta ? ?$ & 181400 ha & 306 ha $\delta$ & $0.2 \% \delta$ \\
\hline Beach forest & $800 \mathrm{~km}$ & $\sim 400 \mathrm{~km}^{\delta} ?$ & $\sim 50 \%$ ठ ?? & $4500 \mathrm{ha}^{* *}$ & 594 ha* a $^{* *}$ & $\sim 13.2 \%$ a \\
\hline $\begin{array}{l}\text { ‘Coastal } \\
\text { forest’ }\end{array}$ & ? & $48^{\prime} 900$ ha $^{\alpha}$ & $?$ & ? & ? & ? \\
\hline $\begin{array}{l}\text { Agricultural } \\
\text { land }\end{array}$ & $1^{\prime} 576^{\prime} 418$ ha & $64^{\prime} 608$ ha ${ }^{\alpha}$ & $2.4 \%$ a & $287^{\prime} 382$ ha* & 1438 ha* a $^{*}$ & $0.5 \%$ a \\
\hline Plantations & $?$ & $28^{\prime} 000$ ha ${ }^{a}$ & $?$ & $6^{\prime} 996^{\prime} 158$ ha* $^{*}$ & $14^{\prime} 123 \mathrm{ha}^{*}$ a & $0.2 \%$ a \\
\hline Aquaculture & $47^{\prime} 620$ ha & $20^{\prime} 429$ ha a & $42.9 \%$ a & 5154 ha* & 42.5 ha* a $^{*}$ & $0.8 \%$ a \\
\hline
\end{tabular}

* Affected Thai Provinces only (FAO-MOAC 2005); ** Thailand only Takua Pa District (Thanawood et al. 2006)

Relevant references

GRCMN 2006, Baird et al. 2005; Foster et al. 2005, UNEP 2005a, BAPPENAS 2005, BRR 2005a, Thanawood et al. 2006, Synergy One 2006, FAO-MOAC 2005, FAO 2005d, EJF 2005, IUCN 2006, NORDECO 2005, FAO-WFP 2005, WIIP 2005, Meilianda et al. 2006, FAO 2005e

Table 1. Estimated percentage damages of natural and agricultural ecosystems along the Thai Andaman coast and in Aceh

\subsection{Offshore ecosytems}

Coral reefs overall seem to have suffered fairly modest impacts from the 2004 tsunami (Pennisi 2005). Along the Thai Andaman coast about $13.2 \%$ of corals experienced a heavy impact of $>50 \%$ damage; $60.4 \%$ of corals were not or just slightly affected (0-10\% damage) (GCRMN 2006). At the most exposed Surin Islands corals suffered only about $8 \%$ of damage with signs of recovery already eight weeks after impact (EJF 2005). At Ko Phra Tong and Ko Ra on the northern Andaman coast some reefs, however, seem to have been heavily affected (up to $80 \%$; IUCN 2006). In Aceh patterns of impact were variable, but overall damage levels appeared to be similar to Thailand despite the generally much higher wave energy along these coasts (Foster et al. 2005). Around Pulau Weh and Aceh reefs were surprisingly little affected; some were intact despite the fact that the tsunami caused severe destruction on adjacent land areas (Baird et al. 2005; Foster et al. 2005). In places of direct heavy wave impact there was only little evidence of recent coral mortality, e.g. according to Baird et al. (2005) an estimated 83\% of corals transported on land appeared to have been dead prior to the tsunami (cf. Fig. 6a). They suggested that with an influx of nutrients flushed from the land the tsunami may only have 
exacerbated a phase shift from corals to algae which was notable before 2004 as a result of bombing and cyanide fishing in the islands. Overall, direct tsunami impacts were highest in colonies on unconsolidated substratum on the reef slope; damage was mainly influenced by reef aspect, submarine topography and it was highest in bays (Baird et al. 2005, Foster et al. 2005; cf. discussion of wave build-up in Cochard et al. 2008). The most dramatic destruction of coral reefs was, however, due to the effects of the earthquake. On Simeulue, Bangkaru and other islands whole reef flats were lifted above the sea level and were thereby destroyed (Foster et al. 2005, GCRMN 2006, Meltzner et al. 2006, cf. later discussion).

According to rapid assessments reported in UNEP (2005a) only 1.5\% of Thailand's seagrass meadows along the Andaman coast experienced total habitat loss, with about $3.5 \%$ being affected by siltation and sand sedimentation. The most impacted seagrass meadows were those of Ko Yao Yai, Phang Nga Province, where an estimated total habitat loss of $10 \%$ was recorded. It was suggested that it will take three months for seagrass to recover from siltation (UNEP 2005a). Seagrass meadows are also found in Aceh in the areas of the Aceh Besar Island group (Pulo Aceh), Weh Island group, Simeulue Island group and the Pulau Banyak group. UNEP (2005) put figures of seagrass beds at approximately 600 ha, but according to WIIP (2005), the little information that was available was mostly qualitative. Figures of tsunami impacts on seagrass beds in Aceh are even more in the dark. They were assumed by WIIP (2005) at 50-100\% losses based on guesses from location and presumed tsunami impacts. As for coral reefs (cf. Baird et al. 2005), the true losses may, however, be considerably lower.

\subsection{Mangrove swamps}

Along the Thai Andaman coast the extensive mangrove ecosystems were only affected at most exposed locations fronting the sea and along creek systems (cf. Cochard et al. 2008), with a total loss of 306 ha or about $0.2 \%$ of Thailand's mangroves (UNEP 2005a). In many areas the impacts were selective, uprooting mainly trees of (predominantly young to medium-aged) stilt-rooted Rhizophora apiculata, while cable-rooted trees of Avicennia spp. and Sonneratia spp. remained largely standing and survived (Cochard et al. 2008). For Aceh the data which was provided by agencies on mangrove forest cover and impacts were highly inconsistent. The most extensive mangrove forests in the Province of Aceh are found in north-eastern areas in Aceh Timur and Langsa Districts (ca. 297'000 ha; WIIP 2005); these regions were hardly affected by the tsunami. Fewer mangroves (ca. 50'000 ha; WIIP 2005) were found on the heavily affected west coast and about 1000 ha on Simeulue Island before the tsunami. BAPPENAS (2005) put early estimates of mangrove 'area affected' by the tsunami at 25'000 ha. BRR (2005a) presented an 'environmental damage indicator' figure of 2711 ha for mangrove area (no source or explanation). Possibly the most reliable approximations are still some figures listed by WIIP (2005), which estimated a loss of $100 \%$ (26'823 ha) for Aceh Besar (north coast, incl. Banda Aceh), 50\% (14'000 ha) in Aceh Barat (west coast), 75\% (17'000 ha) in Pidie (north coast) and 30\% (26'000 ha) in Aceh Utara and Bireun Districts (north coast). According to my own observations, virtually $100 \%$ of mangroves were found dead by July 2006 along the west coast (Aceh Jaya and Aceh Barat), and in the surroundings of Banda Aceh probably $>98 \%$ of pre-tsunami stands had been destroyed. The vast majority of trees had been physically cut or overthrown by the tsunami (Cochard et al. 2008); possibly about $50 \%$ of the trees that initally withstood the impact later died to other secondary effects (excluding an intact stand on Pulau Weh). 


\subsection{Beach forests, sand dunes and beaches}

Thanawood et al. (2006) estimated that $13.2 \%$ of beach forests were affected north of Phuket Island in Takua Pa District, however, without any indication to what degree. Their figure of 4500 ha total cover of beach forest for this district furthermore contrasts with the figure of 1465 ha for the entire Andaman coastline stated by UNEP (2005a). On site visits I found that most stands of Casuarina equisetifolia between Phuket and Laem Son National Park were affected to some degree, but only in a few places there was complete destruction of Casuarina beach forests; in most places only smaller trees were broken (cf. Cochard et al. 2008). Following the tsunami there have also been some shifts in tree species composition of other beach forest stands (e.g. the Barringtonia formation): typical beach forest trees such as C. equisetifolia, Pandanus spp., Cocos nucifera (coconut palms) and Terminalia catappa appeared to be comparatively more resistant to the tsunami impact than other, more generalist species, such as Eugenia spp., Ficus spp. or leguminous trees, e.g. the exotic Leucaena leucocephala (FAO-MOAC 2005, FAO 2005c; Table 2). No detailed data was found in the literature about the impacts on Casuarina beach forests and coconut groves dominating the sandy coasts of western Aceh. Along many stretches of coastline these vegetation types, providing the first line of vegetation resistance against the tsunami, experienced complete destruction (own observations; cf. Kerr \& Baird 2007). Yet, surprisingly, several large trees also managed to survive on the west coast even at most exposed locations (Fig. 2a,b), much in contrast to most of the mangroves. In many cases, Casuarina trees only survived if their roots were protected behind revetments (cf. Meilianda et al. 2006). There is no data from the literature as to what degree beach forests actually prevented sand dune erosion during the tsunami. In Aceh the tsunami impact was massive in terms of wave height as well as velocity and the water masses on the beach front have exerted an immense pressure on sand deposits (cf. Gedik et al. 2005, Heller et al. 2005). In many areas entire beaches and sand spits were washed away (Fig. 2c), some of those beaches were important turtle breeding grounds (NORDECO 2005). A loss of about $50 \%$ of beaches was estimated for the west coast (UNEP 2005a, FAO 2005d).

\begin{tabular}{|c|c|c|c|c|c|c|c|c|}
\hline \multirow{2}{*}{$\begin{array}{c}\text { Vegetation / } \\
\text { species }\end{array}$} & \multicolumn{2}{|c|}{ Direct physical } & \multicolumn{2}{|c|}{ Indirect physical } & \multicolumn{2}{|c|}{ Salinity effects } & \multicolumn{2}{|c|}{$\begin{array}{l}\text { Waterlogging } \\
\text { effects }\end{array}$} \\
\hline & intensity & location & intensity & location & intensity & location & intensity & location \\
\hline Mangroves & $2-3$ & 1 & 1 & 1 & 0 & 0 & 0 & 0 \\
\hline Casuarina & 1 & 2 & 1 & 2 & 0 & 0 & 1 & 1 \\
\hline Ficus & 1 & 1 & 0 & 0 & 1 & 1 & 0 & 0 \\
\hline Eugenia & 0 & 0 & 0 & 0 & 3 & 1 & 1 & 1 \\
\hline Cocos & 1 & 1 & 0 & 0 & 2 & 2 & 0 & 0 \\
\hline Melaleuca* & 1 & 1 & 1 & 1 & $2-3$ & 2 & 2 & 1 \\
\hline $\begin{array}{l}\text { Coastal } \\
\text { forest* }^{*}\end{array}$ & 0 & 0 & 0 & 0 & $2-3$ & 2 & 2 & 1 \\
\hline
\end{tabular}

Table 2. Qualitative indices of tsunami effects on trees as by impact intensity on trees $(0$ no, 1 mild to 3 intense effect) and overall distribution ( 0 none, 1 very localised to 3 widespread); assessment by P. Saenger (FAO 2005a) and, on Ko Phra Tong $\left(^{*}\right)$, by R. Cochard 


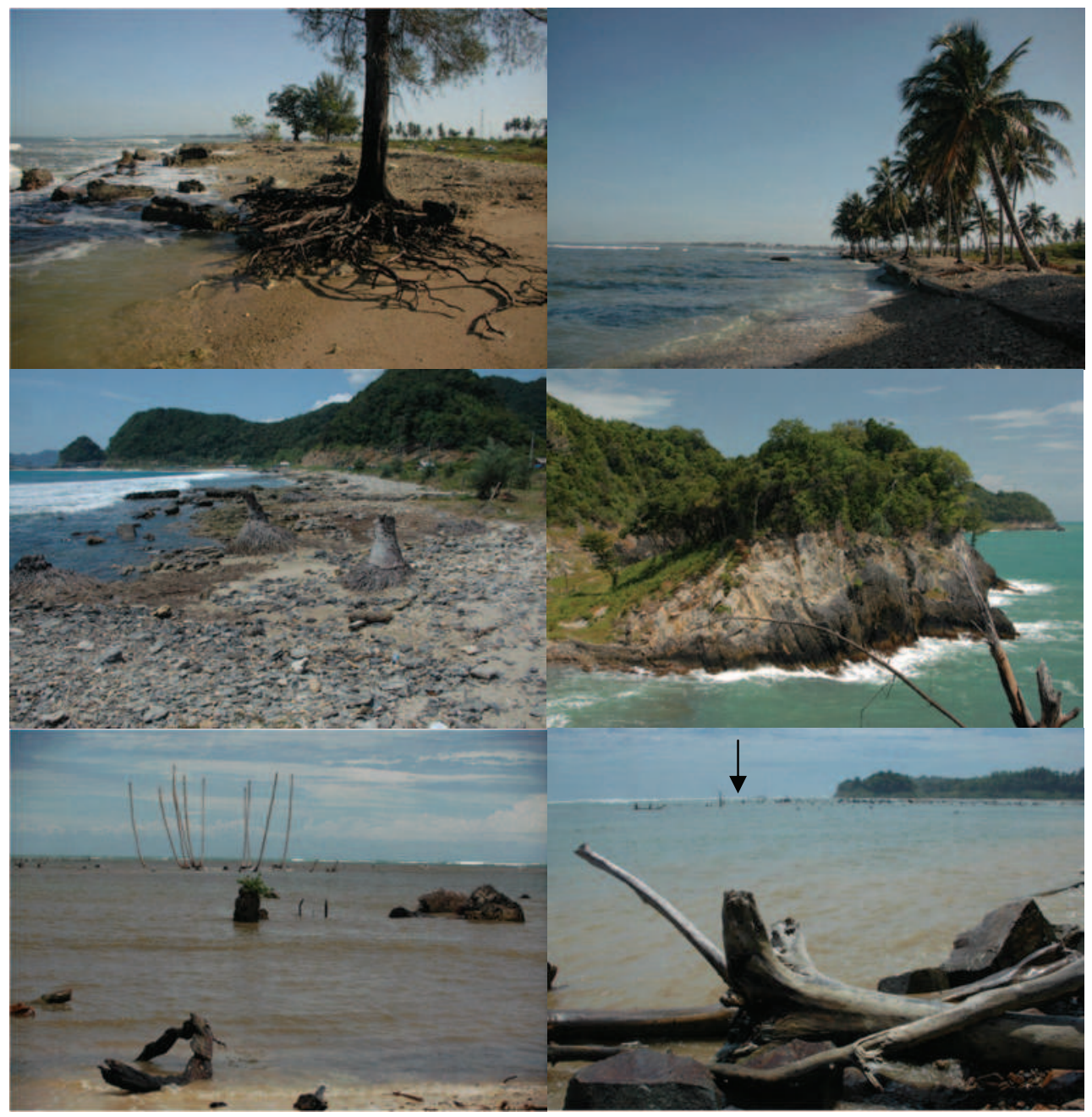

Fig. 2. (a) A Casuarina tree and (b) coconut palms that are (still) surviving near the tip of the Meulaboh peninsula. Virtually all the houses of the town that was densily built behind these trees were completely levelled by the tsunami. Post-disaster reconstruction has been prohibited at this very exposed site. $(\mathbf{c}, \mathbf{d})$ Sand beach erosion and hillside vegetation removal by the tsunami (Ujung Labuhan, South of Lhok Nga), exposing the bare rock surface along the new shoreline and as a trim line along the cliffs. (e) Land subsidence and beach erosion (along the coastline between Lho Kruet and Calang) as evidenced by the submersed and killed coconut palms and (f) former mangrove stands (see line at horizon, arrow), now exposed to open water wave action and erosion. Pictures: R.Cochard, July 2006.

\subsection{Other coastal forestry resources}

The effect of salinity on trees is still barely documented and quantified. FAO (2005a) presented some qualitative data as shown in Table 2. The clear indication is that typical beach trees (e.g. 
Casuarina) that survived the physical impacts did not have any great problems with salinity while inland trees were much more affected. For example, trees in the affected parts of peat swamp forest and freshwater swamp forests in Aceh and in Southern Thailand were probably mainly killed by salinity. Also a majority of trees in the savanna of Ko Phra Tong (Thai Andaman coastline) were killed by the sea salt rather than being physically affected by the tsunami (>50\% killed trees in March 2006, pers. obs.; according to IUCN 2006 only 18\% of trees were killed; Fig. 7a). Possibly about $20 \%$ of the savanna area on Ko Phra Tong was affected by the tsunami. Similar to observations by Gardner et al. (1992), who documented the effects of Hurricane Hugo on a coastal forest in South Carolina, salinity-intolerant tree species were often more affected if standing close to the coastline, in swales or near the edge of marshes. According to BAPPENAS (2005) some 50'000 ha of coastal forests other than mangroves were lost to the tsunami in Aceh; "coastal forest" was not defined in more detail (Table 3). The tsunami also damaged some $28^{\prime} 000$ ha of plantations, a major part of the Acehnese economy (BRR 2005a). A collection of recovery indicators (BRR 2005b) provides no environmental data, but a list of possible vegetation, habitat and other environmental indicators is provided under the heading "indicators for which agencies/organisations did not provide adequate data". Along the northwestern shore the trees and thin soils along the rocky hillsides were generally completely removed by the tsunami, giving an indication about the height of incoming water masses ('trim line'; Fig. 2d).

\section{Anthropogenic impacts on coastal ecosystems in Thailand and Indonesia}

While some beaches and land resources in Aceh were heavily affected by the tsunami, some ecosystems withstood very heavy impacts. Natural stresses, such as tropical storms, earthquakes, volcanoes and tsunamis, as well as disease outbreaks, have shaped coastal ecosystems throughout their evolution and development (cf. Lugo et al. 2000, Tomascik et al. 1997, Cochard et al. 2008). Anthropogenic stresses, on the other hand, are more recent phenomena which in many cases occur in a chronic and cryptic way, their effects often only becoming fully obvious during a catastrophic event (UNEP-WCMC 2006, GCRMN 2006). Different natural and anthropogenic stresses may interact with each other in complex ways. Ecosystems weakened by chronic anthropogenic stresses are likely to be more vulnerable during a catastrophe. Equally, any efforts at post-tsunami restoration of affected ecosystems may be jeopardized, if chronic anthropogenic stresses persist. Such stresses may increase after a catastrophe, as pivotal ecosystem services may have been lost and socio-economic structures may have disintegrated. Coastal resilience, i.e. the capacity to recover from any (catastrophic) disturbance, may be negatively affected in the long term. This section provides an overall account of major anthropogenic stresses and threats to tropical coastal ecosystems; some current figures of impacts for Indonesia and Thailand are provided in Table 3.

\subsection{Offshore ecosystems}

The actual causes of reef decline are commonly difficult to trace back; reef degradation is normally caused by the interaction of several stressors (Hughes \& Connell 1999). Along the coasts of Sumatra the main threats to coral reefs are probably posed by sediment off-flows from land, which are traceable to upland deforestation (GCRMN 2006). According to Abram et al. (2003) major coral mortality in the Mentawai Islands west of Sumatra could be traced to iron fertilization from smoke plumes stemming from the 1997 Indonesian wildfires; although this has also been attributed to pollution by wastewater and sediments (Hoeksema \& Cleary 
2004). On Pulau Weh and Pulau Aceh dynamite fishing had a significant destructive impact (Baird et al. 2005, cf. also Pet-Soede et al. 1999), yet detailed pre-tsunami data do not exist for Aceh. In contrast, along the Thai Andaman coast coral reef status has been surveyed in relative detail by the Thai Department of Fisheries between 1995-1998, and partially between 20032004: $48.8 \%$ of the reefs were found to be deteriorated and only $17.5 \%$ of reefs were in a 'good' to 'very good' condition (Mather 2005, GCRMN 2006). The relative contribution of different hazards was not known. Threats to some coral reefs along the Andaman coast stem from overfishing, coastal development and tourism (GCRMN 2006). The main threat to reefs does, however, seem to be posed by domestic and industrial pollution, particularly in the Gulf of Thailand. Along the Andaman coast it was estimated in 1986 that 1384 tons of domestic BOD (biochemical oxygen demand) load was discharged into the sea annually (Taranatham in Cheevaporn \& Menasveta 2003); today's BOD emissions are probably much higher.

Relatively little is known about the extent and status of seagrass beds in Thailand, and almost nothing in Aceh. According to estimates referred to by UNEP (2004) possibly some $30-40 \%$ of seagrass beds in Indonesia have been lost; estimates of losses for Java are as high as $60 \%$. In Thailand, losses were estimated at 20-30\% (UNEP 2004), whereby higher losses probably occurred in the more polluted Gulf of Thailand, and the Andaman Sea may be less

\begin{tabular}{|c|c|c|c|}
\hline \multirow{2}{*}{$\begin{array}{c}\text { Coastal } \\
\text { ecosystem }\end{array}$} & \multicolumn{2}{|c|}{$\begin{array}{l}\text { Percent affected } \alpha \text {, highly } \\
\text { affected }^{\eta} \text { and destroyed } \delta\end{array}$} & \multirow[t]{2}{*}{ Major threats and impacts } \\
\hline & Indonesia & Thailand & \\
\hline Coral reefs & $\begin{array}{l}86 \%{ }^{\alpha} \\
47 \%{ }^{\eta}\end{array}$ & $\begin{array}{l}77 \%^{a} \\
52 \%{ }^{\eta}\end{array}$ & $\begin{array}{l}\text { overfishing, destructive (e.g. blast or poison) } \\
\text { fishing, pollution (by nutrients, poisonous } \\
\text { chemicals or land-borne sediments), coastal } \\
\text { development, tourism }\end{array}$ \\
\hline Sea grass beds & $30-40 \%$ \& & $20-30 \% \delta$ & $\begin{array}{l}\text { siltation, pollution, mechanical damage (e.g. } \\
\text { trawling) }\end{array}$ \\
\hline $\begin{array}{l}\text { Mangrove } \\
\text { forest }\end{array}$ & $\sim 40 \% \delta$ & (35-) $55 \%$ 8 & $\begin{array}{l}\text { conversion to aquaculture ponds (tambak), } \\
\text { salt ponds and agriculture, coastal } \\
\text { development, mining, fuel production } \\
\text { (charcoal), hydrological changes, pollution }\end{array}$ \\
\hline Beach forest & $?$ & $?$ & $\begin{array}{l}\text { replacement with coconut and other } \\
\text { plantations, woodchipping, coastal erosion, } \\
\text { sand mining }\end{array}$ \\
\hline $\begin{array}{l}\text { Peatswamp } \\
\text { forest }\end{array}$ & $\begin{array}{l}>53 \% \text { a } \\
>32 \% \text { б }\end{array}$ & $?$ & $\begin{array}{l}\text { logging and conversion to agriculture (e.g. } \\
\text { rice fields) and tree crop estates (e.g. oil palm } \\
\text { plantations), or abandonment (secondary } \\
\text { sedge-fern lands), forest fires }\end{array}$ \\
\hline \multicolumn{4}{|c|}{$\begin{array}{l}\text { * Thailand only Takua Pa District (Thanawood et al. 2006) }{ }^{* *} \text { Affected Thai Provinces only (FAO- } \\
\text { MOAC 2005) }\end{array}$} \\
\hline \multicolumn{4}{|c|}{$\begin{array}{l}\text { Relevant references } \\
\text { GRCMN 2004, 2006, Burke et al. 2002, Spalding et al. 2001, UNEP 2004, Green \& Short 2003, Duarte } \\
\text { 2002, FAO 2003, Barbier \& Sathirathai 2003, Alongi 2002, Soegiarto 2004, Dahdouh-Guebas et al. 2005b, } \\
\text { Giesen 2004, Sargeant } 2001\end{array}$} \\
\hline
\end{tabular}

Table 3. Anthropogenic causes of damage to coastal ecosystems in Indonesia and in Thailand with percentage estimates of impacts 
affected. In Indonesia and Thailand the main causes are probably traceable to increased siltation rates in estuarine areas and coastal pollution; as with coral reefs the most likely factors are a combination of several impacts (UNEP 2004; Table 3). Other impacts may be due to chronic mechanical damage, such as trawling, dredging, push nets, anchoring and dynamite fishing; though less important in terms of scale, these impacts are normally unambiguous (Duarte 2002).

\subsection{Mangrove swamps}

Mangrove ecosystems play an important role as a marine pollution control buffer (Mazda et al. 2007, Wong et al. 1997, 1995). It is obvious that a loss of mangroves commonly not only leads to coastal erosion and increased sedimentation but also to higher domestic pollution discharge into the open sea and onto coral reefs or seagrass beds. Often shrimp farm enterprises that have replaced mangroves contribute highly to marine pollution (Dierberg \& Kiattisimkul 1996, Thampanya et al. 2006). The destruction of mangrove ecosystems is therefore often directly responsible for the deterioration of offshore ecosystems, whereas the destruction of offshore ecosystems can also affect the function of mangrove environments (e.g. by increased wave impacts; cf. Cochard et al. 2008).

According to Aksornkoae \& Tokrishna (2003) mangrove forest cover in all of Thailand more than halved between 1961-1997 from 367'900 ha to 167'582 ha; other figures by FAO (2003) suggest, however, that possibly some $240^{\prime} 000$ ha are still remaining. Losses of 61'268 ha of mangroves along the Andaman coastline were by $42.5 \%$ below the total national level (Aksornkoae \& Tokrishna 2003). While there are many reasons for the destruction of mangrove forests, e.g. population pressure, coastal development, mining, conversion to salt ponds and agriculture, the most important single factor in recent years, has been the expansion of aquaculture. Shrimp farming may account for $32.7 \%$ of total mangrove losses with a major expansion from 31'906 ha to 66'997 ha between 1983 and 1996 (Aksornkoae \& Tokrishna 2003, Barbier \& Cox 2002). Other estimates range from 21-64\% contribution to destruction (Dierberg \& Kiattisimkul 1996). On the Andaman coastline, shrimp farm expansion accounted for only $8.4 \%$ according to Aksornkoae \& Tokrishna (2003); the most pristine forests could still be found in Ranong and Phang-nga Provinces, i.e. the areas most affected by the tsunami. An analysis using aerial video recording by Erftemeijer (2002), however, indicated an increase of (partially uncontrolled, illegal) shrimp farms of up to $25 \%$ of mangrove areas. The analysis did not include Ranong Province, but for Phang-nga an area of 5637 ha of shrimp ponds was estimated instead of the previous estimate of 953 ha. That all these areas were mangrove areas appears, however, unlikely: along the Andaman coastline many shrimp farms are built on higher ground (FAO-MOAC 2005). In Indonesia overall estimates of mangrove losses are from an initial $4250 \mathrm{~km}^{2}$ to now about $2500 \mathrm{~km}^{2}$, with most losses recorded along the coasts of Java ( 70\%), Sulawesi ( 49\%) and Sumatra $(\sim 36 \%)$, and the most untouched stands remaining in West Papua (Soegiarto 2004, Chang et al. 2006; Table 5). In Indonesia firewood and charcoal production as well as conversion to tambak are major causes for mangrove losses (Soegiarto 2004). There are no detailed data available for Aceh Province, but on the island of Sumatra the Acehnese mangroves were probably the worst affected already before the tsunami. On the vegetation map by Laumonier et al. (1997) no primary mangrove forest was indicated in all of Aceh; mangrove destruction has been considerable in Aceh already before 1920 (Luytjes in Laumonier 1997). Large areas of mangrove had been in serious decline, and most of the $36^{\prime} 000$ ha of tambak 
(shrimp and fish farm) ponds in Aceh are thought to have been built in former mangrove areas, including the heavily affected area along the coast of Banda Aceh, where most of the mangroves had been cleared during the last 30 years (GCRMN 2006, NORDECO 2005, cf. Parish 2005; cf. Fig. 2a). According to UNEP (2005a) about 8\% of Aceh's total remaining mangroves were considered to be in good condition, $85 \%$ in fair condition and $7 \%$ in poor condition prior to the tsunami. Brackish water forests adjoining mangrove forests are particularly under pressure from wood uses and have also frequently been converted to agricultural land (Whitten et al. 1997).

Cryptic degradation is possibly an underestimated factor leading to higher vulnerability of mangrove forests to coastal wave hazards (cf. Dahdouh-Guebas et al. 2005a). According to Dahdouh-Guebas et al. (2005b) changes to historic systems of freshwater management in some river catchments in Sri Lanka as well as in other countries have increased dramatically in recent times. As a result of hydrological changes, such as inter-basin transfers via canal systems, ecological and socio-economic coastal equilibria in estuarine lagoon environments have been disrupted. While mangrove areas have increased in some cases due to increased accretion of sediments at river mouths, qualitative degradation of mangrove stands in terms of floristic composition, significance of the species, and biodiversity has often been ongoing (Dahdouh-Guebas et al. 2005b). Another possibly underestimated factor of cryptic degradation is chronic pollution. Along the Thai Andaman coast extensive wood chipping for charcoal during the 70ies and 80ies has also lead to major simplification of large areas of mangrove vegetation (FAO-MOAC 2005).

While mangrove destruction may increase the vulnerability of coastal communities overall (cf. Cochard et al. 2008), in Thailand the 2004 tsunami mainly hit areas where aquaculture was still protected by mangroves. In total only 42.5 ha of shrimp ponds were affected (FAOMOAC 2005). In Aceh the situation looks very different: $20^{\prime} 429$ ha, or $42.9 \%$ of aquaculture ponds were affected by the tsunami, thereof 1022 ha were completely lost to the sea and 7270 ha were heavily affected (FAO 2005d; Table 3). Given the strength of the waves in Aceh, we may wonder about what difference it had made if mangroves had still been in place; detailed spatial analyses of available impact data may still provide better evaluations about the actual protection benefit of mangroves versus aquaculture. In any case, sound rehabilitation planning should consider the integration of tambak ponds with mangrove replanting schemes, also to account for their fish and shrimp nursery and wastewater cleaning functions (cf. Cochard et al. 2008).

\subsection{Beach forests, sand dunes and beaches}

Causes of beach erosion may be grouped into five categories: increased wave energy, interruption to littoral transport, deprivation of sediment input, human activities and sea level rise (Wong 2003). There do not appear to exist any detailed pre-tsunami data on beach patterns and changes, neither for Aceh nor for the Andaman coastline. According to Meilianda et al. (2006) the beaches north of Banda Aceh had, however, been experiencing erosion problems for decades before the tsunami. Whether this is related to the replacement of large mangrove areas by tambak aquaculture and the construction of an artificial river bed for the Aceh River and adjacent rivers is unclear. According to Whitten et al. (1997) commercial sand exploitation also had a significant impact on beach vegetation along some coastline stretches near Banda Aceh. The destruction of coral reefs and mangroves may 
cause a change of sedimentation patterns and wave energy on some nearby beaches (Wong 2003). Changes in wave energy can almost totally destroy beach vegetation (Whitten et al. 1997). Casuarina beach forests, however, seemed to be in fairly good shape along most of the Thai coastlines visited even after the tsunami (pers. obs.). Anthropogenic impacts on Barringtonia beach forests in Sumatra as well as Thailand have certainly been considerably higher already in historic times (Whitten et al. 1997).

\subsection{Peat swamp forests}

A major environmental concern which has so far barely been mentioned in any literature is the past and ongoing large-scale destruction of peat swamp forest in the coastal plains of Aceh and other provinces of Sumatra. This dense forest vegetation type may have mitigated the tsunami impact along some coastal stretches (Cochard et al. 2008). Much more important in the longer term is probably that the coastal forest provided a multitude of ecosystem services, thereby enhancing resilience to coastal communities in case of disaster (cf. UNDP 2006). These services are virtually lost by the forests' replacement with oil palm monoculture plantations, which - synonymous to shrimp farm expansion in mangrove areas in the Gulf of Thailand - have expanded at a breath-taking pace during the last two decades (Sargeant 2001, cf. Fig. 5). There are no exact published data, but changes detectible from available satellite images indicate losses of up to $80 \%$ of the extensive Tripa forests in Nagan Raya Province south of Meulaboh since about 1994. Also the few remaining forests north of Meulaboh are currently being cut at an alarming rate, followed by fire destruction and conversion into various types of plantations (pers. obs.). Especially repeated impact of fires precludes any potential regeneration of these forests in the longer term (Bowen et al. 2000, Giesen 2004). The forests at Singkil are indirectly threatened by water drainage in surrounding plantations. Only the Kluet swamps, which are part of the Leuser National Park, still seem to be in a fairly good shape (Dr. I. Singleton, pers. comm.).

\section{Indirect damages and changes within impacted ecosystems}

The longer-term consequences of the destructive impacts on coastal environments are in many cases still unknown. Resilience is the capacity of an ecosystem to 'bounce back' to its original state. This capacity, however, depends on many variables (most importantly including the activities of human beings) which may change during and after disaster events. For most places affected by the tsunami (and this applies in particular to the Province of Aceh) there were virtually no published ecological data available from before the impact (cf. UNEP 2005a). Some inferences about biotic and physical changes may still be drawn from studies of post-tsunami environmental dynamics, comparisons of impacted sites to sites that were not impacted and/or the investigation of impact gradients. Postdisaster coastal geomorphological processes were, however, complex and - at least initially poorly understood (O. Nieuwenhuis, pers. comm.). The same can certainly be said about biological changes and succession patterns, whereby in most cases no systematic surveys were conducted and no detailed and conclusive data exist until today. An understanding of post-disaster ecosystem changes and social dynamics is, however, a pivotal requirement for serious coastal ecosystem restoration projects. This Section provides an overview of some possible indirect and longer-term impacts by the tsunami and the earthquake. 


\subsection{Damages in estuaries and possible secondary impacts on offshore coastal ecosystems}

As virtually all the mangrove areas along the $\sim 250 \mathrm{~km}$ western coastline between Banda Aceh and Meulaboh have been destroyed, the ecological long-term implications of mangrove loss in Aceh will be different to Thailand. Firstly, there may be significant negative medium- to long-term effects on fish stocks and marine diversity. Even though in total the mangrove forest areas along the west coast were relatively small, most of the larger river estuaries were forested with some mangroves. These may have been important ecological stepping stones along the coast for various marine and intertidal organisms. Mangrove swamps in estuaries may have been providing safe nursery grounds for economically important fish stocks along these stretches of mostly dynamic, turbid waters that are fringed almost entirely by abiotic shoreline systems. Thereby estuaries were possibly supplying fish stocks to otherwise isolated fringing reefs; coral fish population movements are typically more localized than for pelagic fish (cf. Mumby et al. 2004).

The destruction of mangrove vegetation may, furthermore, pose a continuing threat to sensible offshore ecosystems. Many of the inland evergreen forests in Aceh continue to be clearcut for wood production at a fast pace, and sediment loads in the rivers have most likely increased significantly in recent times due to soil erosion in catchments. The filter function of mangroves and related vegetation was possibly essential to mitigate excessive sediment discharge by rivers into the open sea and onto nearby fringing reefs and seagrass beds, particularly also as mangrove swamps can serve as a freshwater sponge, attenuating flooding events after heavy rainfall. The effects on a coral reef after a tsunami and subsequent cyclone were, for example, described in Flores by Tomascik et al. (1997). The runoff from the stream was usually directed away from an adjacent fringing coral reef by a small sand bar and carried westward by the longshore current away from the reef. The initial sand bar was destroyed and a different sand bar was formed which then was directing the river run-off towards the fringing reef. After some heavy rains which increased sediment deposition, the reef had been completely smothered (Tomascik et al. 1997).

\subsection{Restoration of mangrove swamps - what changes need to be considered?}

Even if the fast restoration of former mangrove areas may be desirable, such areas may actually no longer be suitable for mangrove replanting. The current regeneration potential of many former mangrove forests seems to be very low, for four main possible reasons: 1.) a new, unfavourable wind and wave environment due to the destruction of protection features; 2.) compression and collapse of completely bare mangrove peat soils; 3.) loss of keystone mangrove infauna during the tsunami; 4.) general land subsidence altering tidal inundation depths and patterns; and 5.) unfavourable change of the rooting substrates by tsunami sediment depositions.

\subsubsection{Increased direct wave exposure}

Many lagoons and enclosed swamp areas formerly protected by sand spits have been opened up to the sea; for example the tambak area in the former mangrove mudplains west of Banda Aceh could for this reason not be reclaimed (NORDECO 2005, Fig. 3a,b). The presence of mangroves has clearly decreased the overall abrasion of mudflats, as roots of mangroves have provided stability to intertidal flats during the tsunami (Fig. 3a,b). However, the complete demise of coastal forelying sand bars is now directly exposing 


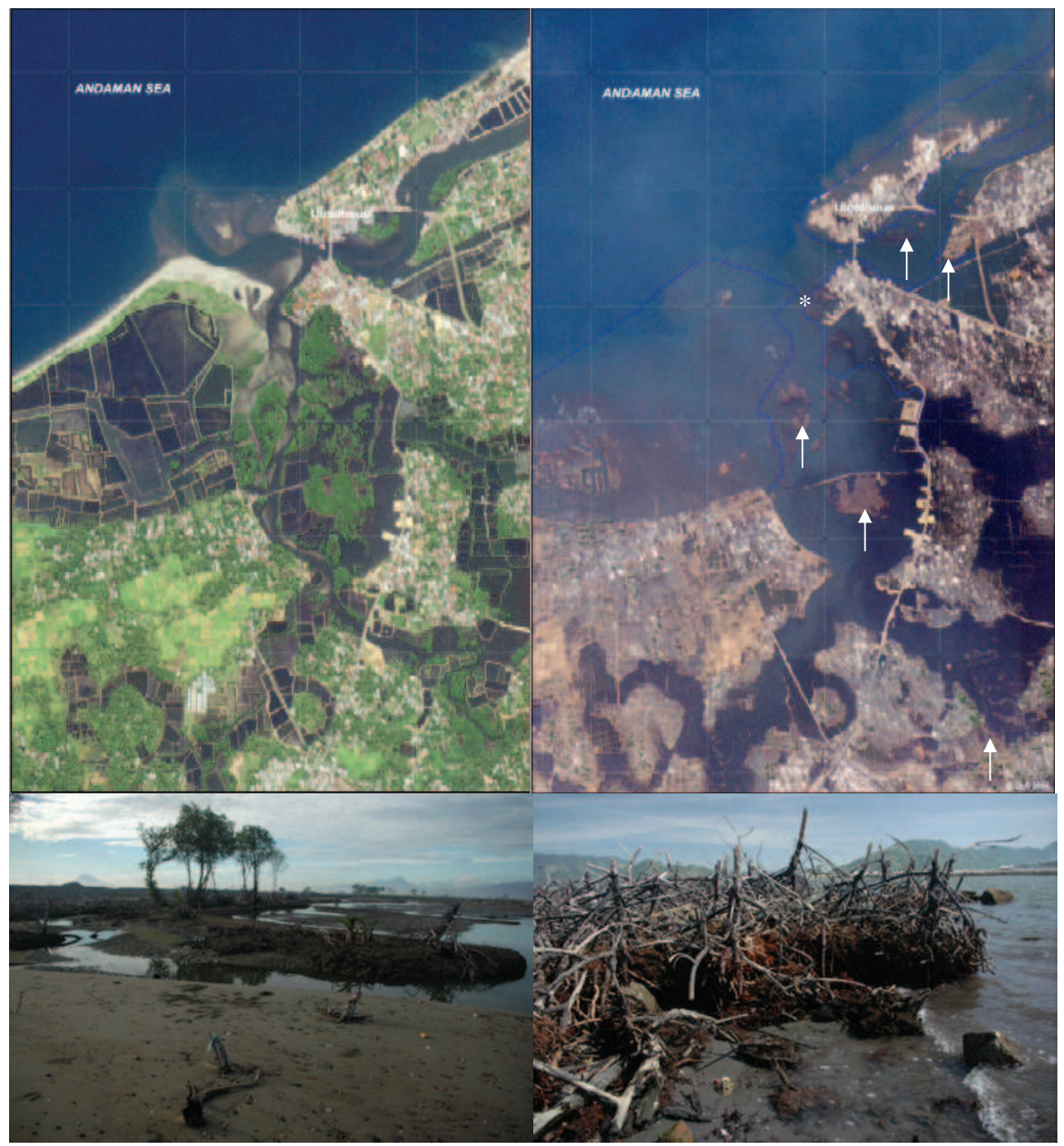

Fig. 3. Part of the northwestern shoreline near Banda Aceh at the port of Uleelheue before and after the 2004 tsunami. (a) IKONOS satellite image taken on 10 January 2003, showing settlements, the extensive tambak fish ponds in the surrounding former swamp area and some remaining mangrove stands in the river estuary and along the rims of tambak ponds (b) IKONOS satellite image taken three days after the tsunami on 29 December 2004. A part of Uleelheue Island, the sand beach to the West as well as most of the tambak areas have been completely scoured by the tsunami waves and form now part of the open sea. As can be seen, intertidal flats still persist in some of the larger former areas of mangroves (arrows). (c) A few surviving larger Rhizophora stylosa trees along the rims of former tambak ponds, close to the sea front near the mouth of Aceh River, North of Banda Aceh. (d) Destroyed 
intermediate Rhizophora stand close to Uleelheue (see asteriks in 10b). With the complete scour of the forelying sand spit during the tsunami, the mangrove peat is now directly exposed to open sea wave impacts and is slowly eroding, increasingly so, as the binding mangrove root remains are also decaying. No root resprouts were observed, indicating $100 \%$ tree death at these sites. Satellite image source: CCI 2006. Pictures: R.Cochard, July 2006.

mangrove mudflats to the physical wave impact of the open seas. As no tree recruitment appears to be occurring and replanting is not successful, the tidal flats are now slowly eroding in the widened bay (Fig. 3d). Also, most mangroves which still had been fringing former tambak ponds have been leveled by the tsunami with the effect that high winds are now freely blowing over the open tambak areas and mudflats. Quite significant waves are thereby produced even within relatively small tambak ponds. These waves probably have a significant impact on unprotected, replanted seedlings (Fig. 4a,b). Unless certain conditions change (e.g. new deposition of sand spits, establishment of wind and wave shields by pioneer plants), there is therefore little prospect of mangrove plantations to be successful in those areas.

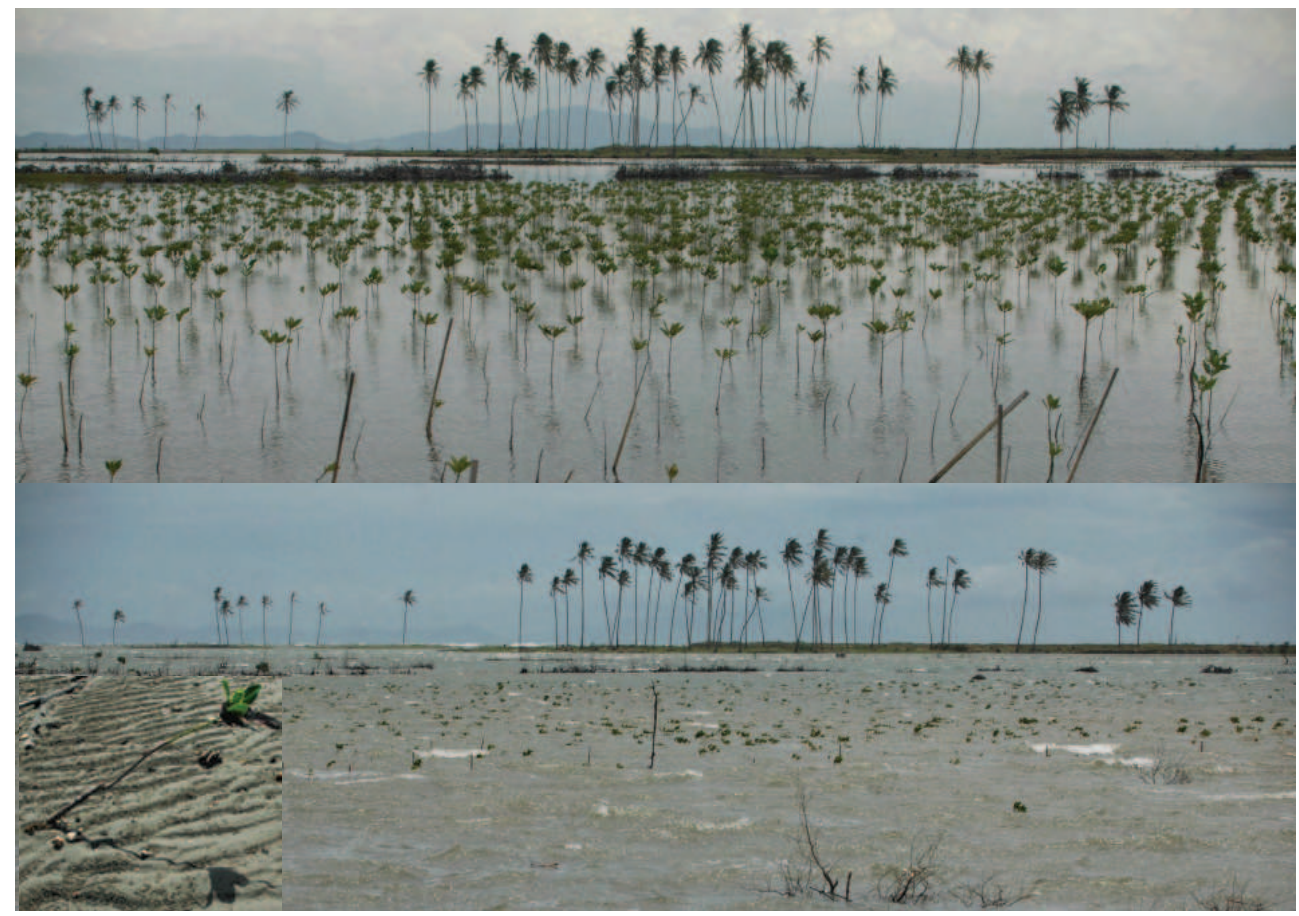

Fig. 4. Newly planted mangrove saplings west of Banda Aceh (a) during low tide and no wind, and (b) during high tide and exposed to wind-driven waves. (c) A surviving sapling after such exposure; it can also be seen that there is a layer of rippled sand deposits.

Pictures: R.Cochard, July 2006. 


\subsubsection{Mangrove peat collapse}

The former peat soils of the extensive mangrove mudflats may now be largely degraded and unsuitable for mangroves, for several reasons. Peat collapse after catastrophic tree mortality has, for example, been reported in hurricane-affected mangrove stands in the Carribbean. Three years after passage of hurricane Mitch, Cahoon et al. (2003) found virtually no mangrove recovery in a former mangrove forest on Guanaja Island, Honduras: neither recolonization by mangrove propagules, nor root growth and also no inorganic sediment deposition. Consequently, the substrate collapsed at a rate of about $11 \mathrm{~mm}$ per year in the basin forest as the dead root material decomposed and sediments were compacted. While continued elevation loss of mangrove peat can affect seedling establishment per se (via a change in the tidal regime), it could also lead to the development of unfavourable soil conditions, such as low redox potential, increased salinity and sulfides, which may further limit the potential of seedling establishment (Cahoon et al. 2003). According to Wanless et al. (in Cahoon et al. 2003), as per 1992 natural recolonization had not occurred in most of the mudflats created by the 1935 and 1960 hurricanes in South Florida; this despite the availability of plentiful propagules in the immediate vicinity.

\subsubsection{Local extinction of mangrove infauna}

With the immense impact of the tsunami waves and the associated destruction of the mangrove forests entire communities of crabs, worms and other mangrove infauna may have become locally extinct. Many species, especially burrowing crabs, may be crucially important to maintain conditions essential for post-disaster re-establishment of mangroves. The keystone role of crabs in mangrove forest sediments has, for example, been demonstrated by Smith et al. (1991) in a 12-month crab removal experiment in Rhizophoradominated forests in North Queensland. On crab removal plots they found significant increases (in some months) of soil sulfide (up to $\times 1.4$ as compared to control plots) and ammonium (up to $\times 1.8$ increase) concentrations. This affected forest growth and tree reproductive output. Smith et al. (1991) primarily noted aeration of the soil by crab burrows as a most important factor to explain their results, but the flushing function of crab burrows for excessive salt removal, as well as nutrient provision to roots is probably of similar importance (Ridd 1996, Stieglitz et al. 2000).

\subsubsection{Land subsidence or uplift following the $\mathbf{2 0 0 4}$ earthquake and aftershocks}

Elevation levels of former mangrove mud flats were - respectively still are - not only slowly subsiding because of peat collapse and erosion during and after the tsunami. One of the greatest problems in Aceh for the restoration of coastal and particularly estuarine environments appears to be associated with general land subsidence resulting from the 26 December 2004 earthquake and several later aftershocks. Most of the earthquake-related uplift and subsidence became evident after the first earthquake, which is the second strongest on record globally $\left(M_{w} \approx 9.2\right.$; Lay et al. 2005). The island of Simeulue to the southwest of the epicentre was mostly uplifted (some southwestern areas of Simeulue slightly subsided) with a maximum uplift of $2.4 \mathrm{~m}$ recorded at Salaut Island north of Simeulue (Jaffe et al. 2006, Meltzner et al. 2006). The coastal areas of Sumatra northeast to the epicentre subsided. Meilianda et al. (2006) recorded land subsidence at between $0.75-1.75 \mathrm{~m}$ near Uleelheue close to Banda Aceh. This significant subsidence appeared, however, also related to scour by the tsunami (Fig. 3b). At Jantang on the west coast between Banda Aceh 


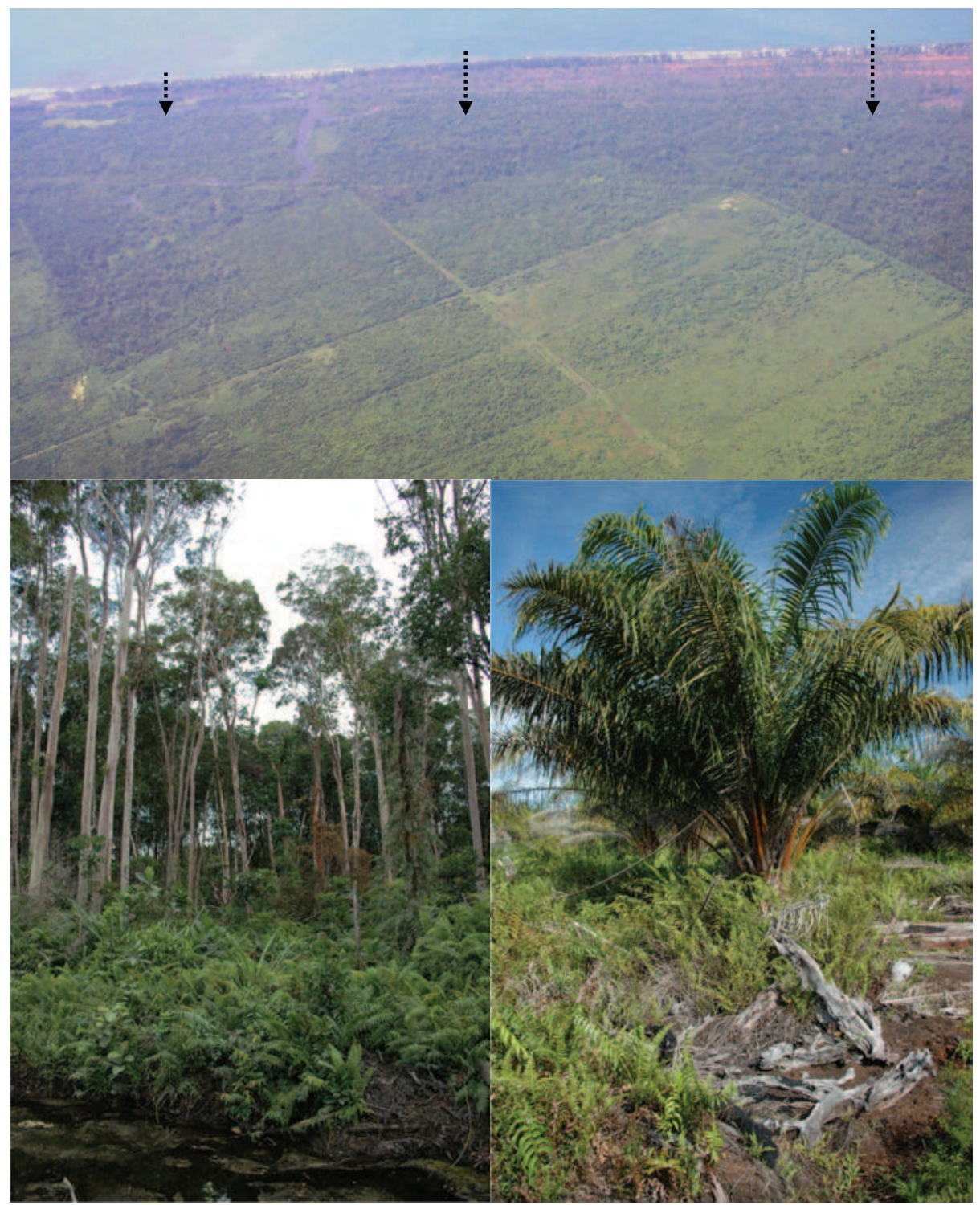

Fig. 5. (a) Aerial picture near the Tripa estuary South of Meulaboh, West Aceh coastline, showing the tsunami-buffering by a strip of remaining peat swamp forest. The picture also shows some of the extent of forest destruction by oil palm companies. In this area more forest was cleared than could actually be planted with oil palms and/or the soil conditions were found to be unsuitable. Secondary forest regeneration is clearly visible within the cleared areas. (b) An intact stand of peat swamp forest along the coastal road North of Meulaboh. (c) Peat swamp forest converted to oil palm plantations in the Tripa region. Aerial picture source: Dr. I. Singleton; other picutures: R. Cochard, July 2006. 
and Calang Jaffe et al. (2006) estimated minimum subsidence at $0.6 \mathrm{~m}$ based on vegetation marks; at a near location they recorded a maximum subsidence of $2 \mathrm{~m}$, but this may also be related by some extent to local scour. Estimates by Meltzner et al. (2006) based mostly on analyses of GIS data put minimum subsidence at the Banda Aceh coast and along the west coast at below $20 \mathrm{~cm}$, emphasising however the uncertainty of these estimates which are based on a relatively weak database. In June 2006 subsidence seemed to be obvious all along the western coastline north of Meulaboh (pers. obs.) and may have been at an equal range at Lho Kruet and at Padang Selimeng close to Calang (Fig. 2e,f).

According to Bilham (2005) the 2004 tsunami was triggered by the initial rupture at the plate boundaries which occurred at typical speeds only in the south. At its northern end of the fault line, the surface between the Indian plate and the Andaman archipelago took more than half an hour to slide a distance of 7 to 20 meters. There the slip was too slow to trigger a tsunami - fortunately, considering that tsunamigenic waves triggered in these parts along the faultline would probably have caused considerably more widespread destruction along the coastlines fringing the Andaman Sea and the Sea of Bengal. Most vegetation changes on the Andaman Islands that were described in the 'tsunami' paper by Roy \& Krishnan (2005) are therefore actually linked to land subsidence rather than to the tsunami impacts. Additional changes in land elevation levels may have occurred later. According to Lay et al. (2005, p. 1129) the most notable aftershock feature was a "swarm of strike-slip and normal faulting events in the Andaman Sea back-arc basin involving more than 150 magnitude 5 and greater earthquakes that occurred from 27 to 30 January 2005." A second large earthquake occurred on 28 March $2005\left(M_{w} \approx 8.7\right)$, with the epicentre close to Nias Islands, where about 1300 people were killed by the quake. This earthquake also triggered a minor tsunami that destroyed several houses on Nias Island; more significantly it also caused significant topographical changes. The small Sarangbaung Island north of Nias Island subsided by about $1.7 \mathrm{~m}$ while reefs on the west coast of Nias were uplifted by about $2.5 \mathrm{~m}$ at Afulu and 1-2 $\mathrm{m}$ at Asu Island and are now exposed above sea level (USGS 2005).

According to Cochard et al. (2008) a sizeable mangrove forest in the Rigaih River floodplain first survived the tsunami, but died later. The exact time of the dieback is not known, but it probably occurred within weeks after the tsunami; its most important cause was likely to be land subsidence and the associated physiological stress due to root asphyxiation and possibly salinity changes. Widespread mortality of Rhizophora and other mangrove stands due to land subsidence has so far only been reported from the southern parts of the Andaman Islands and from the Nicobar Islands where some of the Indian territories' most pristine mangrove stands still existed before the tsunami (Roy \& Krishnan 2005, Ramachandran et al. 2005, Rama Chandra Prasad et al. 2009). Roy \& Krishnan (2005) speculated on some possible successional vegetation changes that may occur, such as replacement of Rhizophora spp. by Bruguiera spp. and/or Avicennia and Sonneratia spp. on elevated, less frequently inundated mudplains, or vice versa establishment of Rhizophora spp. in slightly subsided areas previously occupied by other mangrove species. Meilianda et al. (2006) reported on how after the tsunami typical mangrove crab burrows were found on more elevated locations along the coastline of Banda Aceh, such as in coconut groves. This was also observed in Raya Bay (pers. obs.). From a purely scientific viewpoint, the ecological changes occurring along the coastlines of northern Sumatra and the Andaman Islands may actually provide some unique research opportunities regarding the environmental effects of short-term sea level changes due to seismic activity, possibly with some lessons also for longer-term changes due to climate change. On a more practical side, efforts of mangrove 
rehabilitation can only meet with success if the relative sea level changes are actually made understood prior to replanting - either by detailed reconnaissance surveys and modelling approaches and/or by trial-and-error recursive learning processes (cf. Gross et al. 2005, Gross \& Hoffmann-Riem 2005).

\subsubsection{Marine sediment deposition in mangrove swamp areas}

Another factor which may initially have been causing secondary dieback of mangrove stands may have been excessive sedimentary deposition by the tsunami (Fig. 6b). According to Ellison et al. (1998) natural sedimentation rates of mangroves are in a range normally lower than $0.5 \mathrm{~cm} \mathrm{y}^{-1}$, with a maximum of about $1 \mathrm{~cm} \mathrm{y}^{-1}$, whereby Rhizophora spp. with stilt roots appear to be slightly less sensitive than species with pneumatophores, such as Avicennia and Sonneratia spp. Tree death is also more likely to occur if roots are being smothered by fine sediments, probably because aeration is lower than in rough sediments

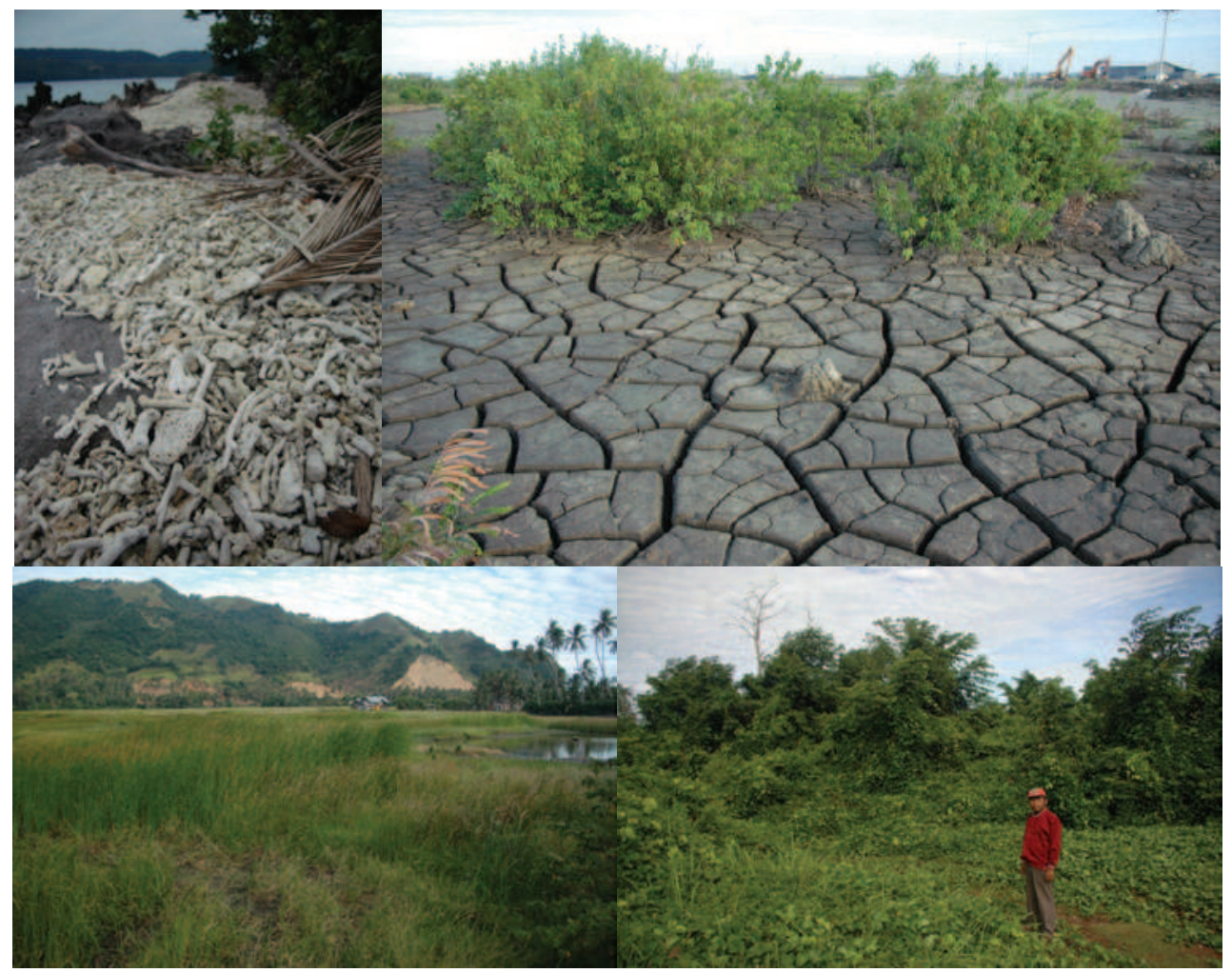

Fig. 6. (a) Coral fragment tsunami deposits on a rock coast on Weh Island North of Banda Aceh. (b) Tsunami mud deposits about $1 \mathrm{~km}$ from the coast North of Banda Aceh. Note the crab burrows, possibly indicating land subsidence. (c) Former paddy fields near Lamblang, West of Banda Aceh. In July 2006 these fields were swamps dominated by Typha angustifolia and sedges. (d) Post-tusnami forest regrowth that is mainly dominated by leguminous tree species. Pictures: R. Cochard, July 2006. 
such as sand (Ellison et al. 1998). No study was found about tsunami deposits in mangroves. It is possible that sediment changes may also explain the success of Nypa palms and Acrostichum ferns to recolonize mudflats; in a wide range of brackish water conditions these species have probably also a wider tolerance of different sediment substrates (cf. Fig 1c).

\subsection{Marine sediment deposition, salinisation and vegetation changes inland}

Large tracts of other open land have been affected by marine sedimentary depositions and salinisation, particularly along the coasts of Aceh. Moore et al. (2006) provided a detailed description of sedimentary deposits along a $450 \mathrm{~m}$ transect south of heavily affected Lhok Nga (west of Banda Aceh): while soils were mostly scoured in the first $\sim 50 \mathrm{~m}$ of impact along the transect (cf. Fig. 2c), the sediment layer thickened progressively from 50 to $100 \mathrm{~m}$ distance, was then about $10-20 \mathrm{~cm}$ thick until at $\sim 375 \mathrm{~m}$ distance from the shore, and then abruptly thinned out to the hillside. A very similar pattern of scour $(0-50 \mathrm{~m})$ and deposition (50-750 m) has been described by Gelfenbaum \& Jaffe (2003) for the 1998 PNG tsunami. Along the western coast tsunami deposits were mainly of sandy texture, whereas the deposits in Banda Aceh were more fine-grained (Jaffe et al. 2006, Meilianda et al. 2006; cf. Fig. 6b). Typical thickness of deposits was $5-20 \mathrm{~cm}$, with a recorded maximum of $70 \mathrm{~cm}$. Thickest tsunami deposits did not correlate with the deepest tsunami flow depth, but were due to various other factors, including the presence of swales. Deposits were normally composed of multiple layers, representing deposition during multiple waves and/or during uprush and return flows (Jaffe et al. 2006). Szczucinski et al. (2005) provide data of sedimentary deposits for several sampling sites along the Thai Andaman coast, whereby sediment thickness ranged from $1-20 \mathrm{~cm}$.

According to BRR (2005b) 64'608 ha of productive agricultural land have been affected by the tsunami in Aceh, representing $2.38 \%$ of the province's total productive area. Thereof $32.7 \%$ have been rehabilitated until December 2005. Land damages due to salinity, and desurfacing of the landscape due to deposition of sand and clay sediments have been mapped for the four most affected districts by Synergy One (2006) using a combination of ground sampling and remote sensing techniques. They estimated that 8118 ha of productive paddy fields or $13.2 \%$ of the total were affected and needed to be rehabilitated. 732 ha of paddy fields were completely lost to scour and to the sea water ("sunk areas"); some of these low-lying areas may now instead be used for aquaculture or mangrove plantations (Slavich 2005; cf. Fig. 3a,b).

The impact of salinity in Aceh and elsewhere was variable. Generally, total salt depositions were highest in areas where sea water had been trapped and logged (Slavich 2005). In these areas production of rice and other crops was often highly diminished. In less affected paddy areas rice production was, however, not affected. In many cases yield even seemed to have increased after the tsunami; although some plant nutrients can be mobilized by salt penetration (cf. Gardner et al. 1992), this was, however, probably mainly attributable to improved irrigation schemes following an inflow of agricultural aid (Young 2005, Slavich 2005). It appears that salt generally did not penetrate deep into the coastal clay soil in which rice is usually grown; on the other hand crops growing on sandy soils, such as peanuts, were negatively affected on all the fields hit by the tsunami (Young 2005). It is, however, assumed that negative impacts will not last as salt is washed out by plentiful rainfall in the wet seasons (Young 2005). Even if lands remain potentially productive, major changes in land use along the west coast of Aceh may simply result from the fact that up to $80 \%$ of the population were killed by the wave in some of these areas (Slavich 2005). 
Apart from agricultural assessments there is so far only very sparse data available from the literature on how salinity or sediments changed the vegetation in the ground layer, particularly in Aceh. Several $\mathrm{km}^{2}$ of former paddy fields between Banda Aceh and Lhok Nga were permanently flooded with sea water (Borrero 2005). Much of these areas are now swamps that are dominated by Typha angustifolia and sedges (Fig. 6c). Typha spp. are known to be very tolerable to various pollution stresses, possibly including elevated levels of salinity (Koottatep et al. 2005). In any case, Typha spp. absorb pollutants, so that many areas may be rehabilitated naturally and could later again be returned to agricultural use as paddy fields.

As could be expected, many creeping pioneer herb species such as Ipomea pes-caprae, Gloriosa superba and Chromolaena odoratum rapidly increased in the beach forests after the tsunami along the Thai Andaman coast (FAO 2005b). Especially I. pes-caprae but also other typical creeping beach species such as Canavalia rosea seemed to be stabilizing many of the sand dunes along the Thai and the Aceh coasts which were left bare and unstable after the tsunami. Further inland, secondary regrowth on flat wasteland was observed to be very fast in some areas, exceeding $8 \mathrm{~m}$ in height in July 2006; fast growing leguminous trees were dominating (Fig. 6d). In some tsunami-affected coastal areas regrowth of typical pantropical and exotic weeds, such as Calotropis procera, Lantana camara, Senna didymobotrya and Leucaena leucocephala was found to be widespread. According to IUCN (2005c) exotic species like Opuntia dillennii or Prosopis juniflora may pose a problem after the tsunami in Sri Lanka. The extent of any such problem has, however, not been established. In Florida Horvitz et al. (1998) found increases in exotic species in hardwood forests after Hurricane Andrew, possibly leading to some long-term shifts in species composition and replacement of native functional groups.

\subsection{Natural and human-aided regeneration processes}

In Thailand most of the tsunami-affected mangrove areas have been replanted (mostly with R. apiculata) and regeneration appeared to be largely successful at most sites which I had visited in March 2006. At some sites natural regeneration by resprouting from root stumps was also observed (Fig. 1b). Overall, it shows that the impacts were more transient, and secondary succession proceeded at a relatively fast rate as ecosystems were to a large degree still intact. In contrast, in Aceh replanting schemes with Rhizophora, Avicennia and Bruguiera seedlings in the mud-flats and along the west coast so far appeared to be largely unsuccessful (Fig. 1a,e), with the exception of a small, only partially affected stand on Pulau Weh, where planted seedlings appeared to be generally surviving. Except in a destroyed Avicennia stand in Raya Bay, I observed virtually no natural mangrove regeneration in Aceh from resprouting, indicating mostly complete mortality. Some areas (possibly $\sim 10-20 \%$ ) were, however, recolonised by mangrove palms, Nypa fruticans, such as close to the mouth of the Aceh River just north of Banda Aceh (Fig. 1c). Also mangrove ferns, Acrostichum aureum, were a commonly found coloniser species in destroyed mangrove mudflats.

In stands of Casuarina beach communities high natural recruitment of seedlings was observed in most of the affected stands of Casuarina trees (Fig. 1d). Equally in Aceh, natural regeneration - where some trees were still standing - as well as replanting schemes appeared to be largely successful behind some intact sand dunes. In many areas sand dunes were, however, completely eroded, or continuing sand deposition and shifts of dunes was preventing successful recolonisation for the time being until a new equilibrium would be reached (Fig. 2c; cf. Liew et al. 2010). 
In a Melaleuca savanna on Koh Phra Tong no regeneration was obvious after the tsunami (Fig. 7a), as seedlings of Melaleuca and other tree species were observed almost exclusively in non-affected areas. Prolific seedling recruitment was in particular observed in a recently burned area unaffected by the tsunami (Fig. 7b). It is possible that Melaleuca seedling establishment was not only facilitated but also triggered by savanna fires. In contrast to statements by IUCN (2006) whereby fires should be prevented, fires could actually represent an intrinsic ecological process in this vegetation type (cf. also Stott 1990, Finlayson 2005) and may potentially serve as a savanna regeneration process following the tsunami.

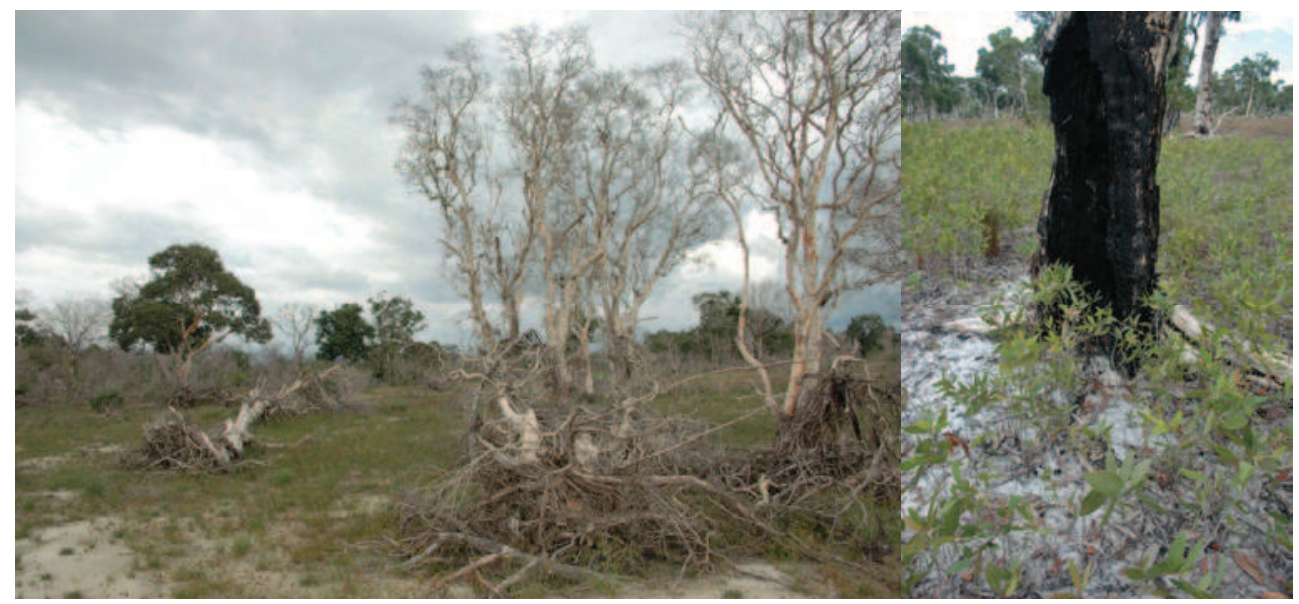

Fig. 7. (a) Tsunami-affected Melaleuca savanna on Ko Phra Tong, Thai Andaman coastline. Most of the trees were killed by salinity. No seedling regeneration was evident in the grassland affected by tsunami salinity and sediments, but (b) vigorous seedling recruitment was observed in a pristine savanna that had evidently been affected by fire a few weeks earlier. Pictures: R. Cochard, July 2006.

\subsection{Future research}

There is an urgent need for detailed scientific assessments on the causes of mangrove plantation failures. On the other hand, research into natural post-tsunami mangrove regeneration processes appears to be advisable, as it may provide some useful clues on how to avoid such costly failures of plantation schemes in future. Albeit FAO (2005e) was drawing attention to the negative effects of increased salinity on Nypa in some areas, in many other areas Nypa and Acrostichum possibly seem to act as essential, first pioneer plants initiating an ecological succession. On the other hand, these species may also indicate that some areas may now be more freshwater dominated; according to M. Nasir (pers. comm.) for some reason it also appears that in several areas in the Banda Aceh plains brackish water and freshwater fishes are now more commonly found than before the tsunami.

There may be a lot which can be learnt in terms of natural history of the region - this in turn may actually be helpful for future risk management, including disaster mitigation and ecosystem restoration. For example, by analysing the morphology of coral microatolls and using them as palaeogeodetic 'natural tide gauges' Natawidjaja et al. (2004, 2006) reconstructed the historical vertical deformations associated with subduction in western 
Sumatra. Their coral records revealed interseismic submergence before and after major earthquake events (e.g. in 1797, 1883, 1935, or also some aseismic slips or "silent events" such as in 1962) in areas of coseismic emergence close to the Sumatran fault line (ie. mainly Mentawai Islands); likewise interseismic emergence occurred in areas of coseismic submergence that are at a greater distance to the fault line (ie. mainland coastal Sumatra). Large seismic events including major mainland subsidence and island uplift, such as in 1833 and 2004/2005, on average seem to occur about every 230 years in the central sections, and probably in other sections of Sumatra as well (Nalbant et al. 2005, G. Prasetya, pers. comm.). Hardly any consideration has so far been given in literatures about the possible effects that this observation may have on coastline evolution and ecosystem dynamics in the area. Along some coastlines of Indonesia mangroves may occur in 'drowned bedrock valleys', i.e. geomorpholocial settings that have been sunk by land subsidence. Tomasik et al. (1997, p. 941) stated, however, that "it is most likely that this type will be rare in the archipelago, given the tectonic nature of the region, where uplift (ie. regression) is relatively more common than subsidence". Given new recent observations, such statements may soon face revision. In the Rigaih River valley and elsewhere along the west coasts of Sumatra, mangroves possibly would have been replaced by peatswamp forests over time, would there not have been intermittent events of land subsidence (cf. Cochard et al. 2008). According to Natawidjaja et al. (2006, p. 32), in order to improve the information base on subduction plate deformations, "paleoseismic work in the marshes and estuaries of the mainland coast would likely yield important results". It would certainly also yield important baseline data useful to interpret coastal landscape evolution in the region.

\section{Concluding remarks: the costs of failing to invest in human and scientific capital}

May it be that post-disaster pressures to reconstruction prevailed over proper planning based on careful analysis of coastline changes, or may it be that the changes were indeed too changeable and complex to interpret in a short time period: several coastal stretches, particularly near the towns of Meulaboh, Calang and Banda Aceh, have been stabilized with hard engineering structures frequently without any proper understanding of their wider impacts or even an assessment of their necessity (cf. Fig. 8). Such concrete structures were not only expensive and unattractive (e.g. to future tourism), they most likely had a significant influence on beach processes. In several cases they were simply misplaced investments buried in sand: as can be seen on Fig. 8a concrete boulders were also placed along coastal stretches where sedimentation rather than erosion was the dominant process. Compared to such concrete investments, lush beach and mangrove forests may appear like an alternate dream.

In Aceh more than 7000 hectares of coastal swamps have been replanted with mangroves in 2005 in just one project - 2550 ha on West coast and 4600 ha on the East coast (cf. Kanagaratnam et al. 2006). Planters employed in this project received US $\$ 0.04$ per planted propagule (on the basis of cash-for-work; Kanagaratnam et al. 2006). If we consider a planting density such as is commonly used in Thai mangrove forestry, e.g. about $25^{\prime} 000$ propagules planted per hectare (Homcha-Aim 2010), this would amount to a total investment of over 7 million US\$. From our observations (cf. Introduction) plantation densities may have been lesser, and plantation implementation more patchy rather than systematically covering large areas. Most of the plantations along the West coast were, 


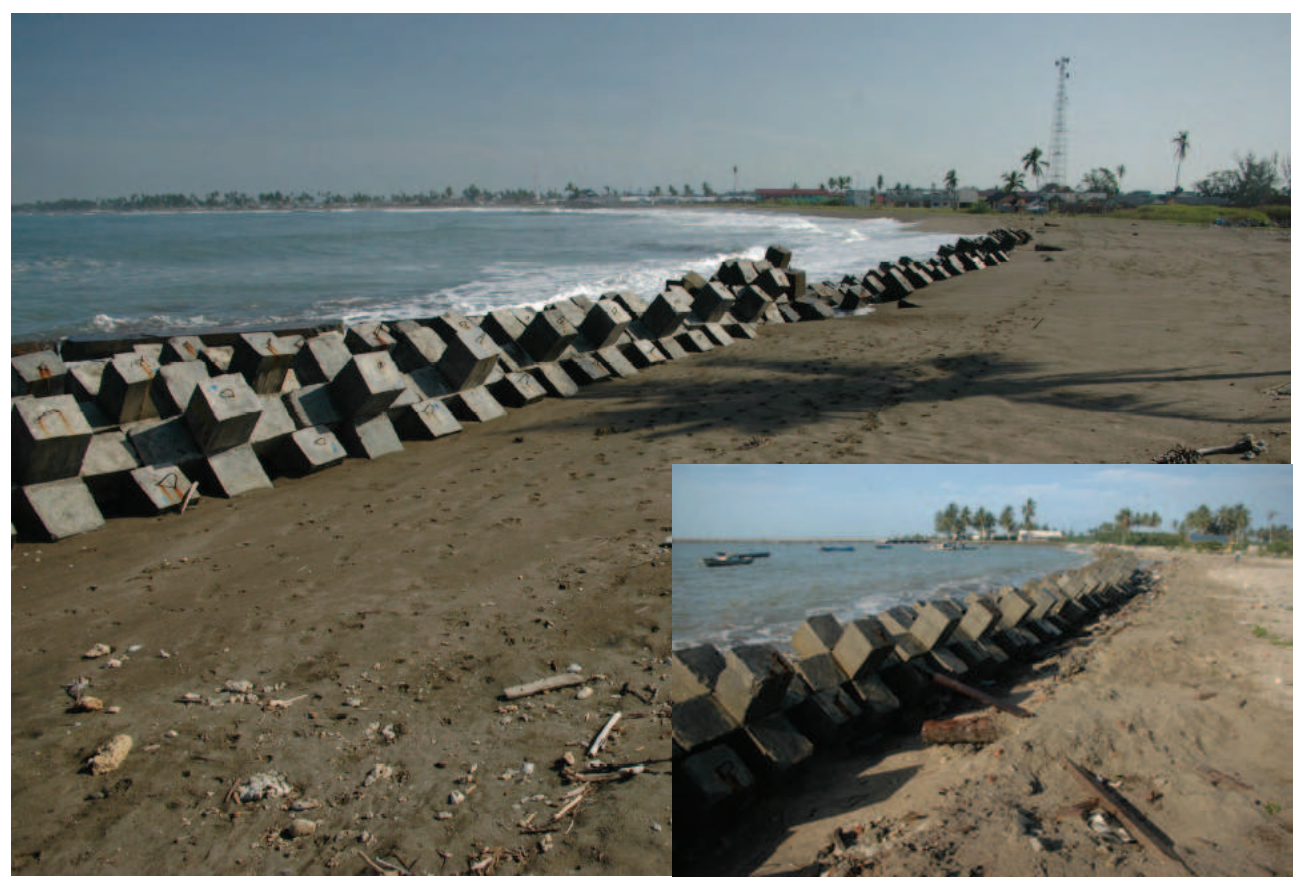

Fig. 8. Protective concrete structures set in place along (a) northern and (b) southern coasts of the Peninsula of Meulaboh. Note that only the southern coasts were actually eroding; along the northern coasts the beaches were accreting.

however, most likely a complete failure, i.e. a foregone investment which may amount to over 2 million US\$ for just this project. There were many other projects in Aceh and elsewhere, in total probably amounting to several million US\$, that were invested in a very short time period - too often in the wrong locations and typically in want of a longer-term strategy. Even more disconcerting than the careless use of aid money may eventually be the bitter realization that these projects have actually served as a vehicle to educate local people that mangrove planting and management is essentially a nonsensical activity. If the big aid agencies (employing entire village communities) could not do it, how then should the "locals" be able to do it?

Most of the explanations for the failures of these plantations related to organizational and social aspects of the concerned projects. Wibisono and Suryadiputra (2006), for example, listed various failures, such as mistakes in the selection of planting sites, unsuitable choice of plants, insufficient preparation, inadequate guidance, the low capacity of human resources, poor coordination and information sharing among the stakeholders concerned with the rehabilitation activity, and the very limited amount of community involvement in the rehabilitation activity. They noted (p. iii) that "a mistaken perception among the implementers was that rehabilitation activity ended once the seedlings had been planted in the field. The result as they saw it, therefore, was the number of seedlings planted, not the number that survived after planting." The true problem behind such an observation may, however, be the practice by which aid funds in general are being used by large international organizations: as depicted in Fig. 9 most of the funds for reconstruction had to be spent 
within only a few years. This is certainly not long enough to foment the foundations for sustainable management of a mangrove forest. But do we actually need to plant mangroves after a disaster? Or is it really something completely different which is needed, e.g. observing, learning and spreading the lessons of the "black swan"?

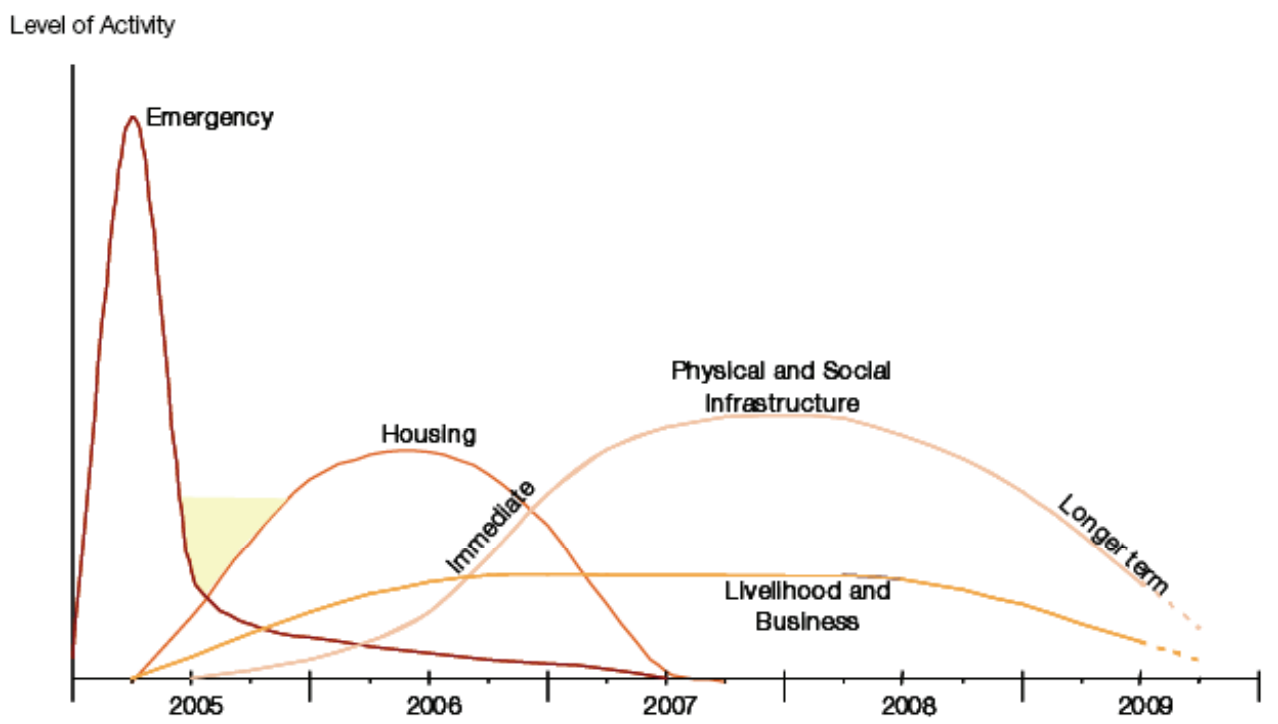

Fig. 9. Sequencing of emergency and recovery efforts after the tsunami in 2004 (adopted from BRR 2005a, p. 19).

The devastation wrought by the tsunami has highlighted a potentially important role of coastal ecosystems for protection of communities from tsunamis and other sea-borne natural hazards. While there exist many anecdotal accounts about the life-saving role of mangroves and coral reefs, truly analytical studies are nonetheless still scarce; the studies so far presented are mostly relatively simple and fail to address the complexity and multidimensionality of the issue (cf. Cochard et al. 2008). Irrespective of their tsunami risk mitigation functions, coastal ecosystems are in any case an asset in the daily lives of coastal communities, and in particular during and after disaster events. Greenbelts - and this term in a wider sense may include other biotic systems that are not actually green - can significantly contribute to both, decreasing vulnerability as well as to increasing resilience of the coastal resource base and therefore of the communities themselves. As an aide-memoire to emphasize this point the final, commendable paragraph of the publication by Baird et al. (2005, pp. 1928-1929) is reprinted here: "Acehnese reefs in the wake of the tsunami provide a profound example of the resilience of marine ecosystems to natural disturbance and also a powerful reminder of the potential for damage from chronic human misuse. The extent of the damage on land and the tragic human cost should not distract attention away from the perennial problems of marine resource management: improving water quality, reducing fishing pressure, and encouraging sustainable coastal development. Neither the conservation priorities nor the risks to reefs have been changed by the tsunami, and it is vitally important that resources are not directed to short-term, small-scale rehabilitation 
programs, which will not reverse long-term declines in reef condition. The political goodwill and the financial resources the tsunami has generated should rather be used to build economies and societies that provide resilience in both the social and the ecological domain." How better to build such societies than by investing in long-term managementcum-research-cum-education programs? And how better to not waste resources in the first place by starting with the appropriate surveying and research after a disaster - before large plantation schemes are let lose founded on error rather than logically conducted trial? Any such "trials" should be accompanied by the expertise of scientists early in the rehabilitation process (optimally involving an education component). As has been suggested by McAdoo et al. (2009) interested scientific experts could be organized in a specialized fast-response team; such a team could serve to consult and accompany NGO's reconstruction efforts, but would operate independently in order to ensure scientific objectivity and credibility.

\section{Acknowledgements}

This review and the field visits to Southern Thailand and Aceh Province were made possible through the financial support of the Centre for International Agriculture (ZIL Grant No No. 41-3219.4/00256) and the Institute of Integrative Biology, Swiss Federal Institute of Technology (ETHZ). Thanks go to Ms. B.R. Bürgi (ETHZ) for helping to organise the field excursion to the Thai Andaman coast, to Mr. M. Nasir (Syiah Kuala University, Banda Aceh) for spending his time (and car petrol) to show R. Cochard the coastline east of Banda Aceh, to Prof. Dr. Sudarmadji (Jember University) for his company during the trip to Meulaboh and Ms. R. Frey (Paneco Foundation, Switzerland) for leading the way to the remaining Tripa swamp forests. I acknowledge the kind permission to use the image in Fig. 1e from Dr. B. McAdoo, Quickbird and Ikonos satellite images in Fig. 3 from the German Aerospace Centre (Deutsches Zentrum für Luft- und Raumfahrt, DLR, http://www.zki.caf.dlr.de/ media/download/applications/2004/indonesia/), and aerial picture in Fig. 5 kindly provided by Dr. I. Singleton.

\section{References}

Abram N.J., Gagan M.K., McCulloch M.T., Chappell J. \& Hantoro W.S. (2003). Coral reef death during the 1997 Indian Ocean dipole linked to Indonesian wildfires. Science 301: 952-955.

Adger W.N., Hughes T.P., Folke C., Carpenter S.R. \& Rockström J. (2005). Social-ecological resilience to coastal ecosystems. Science 309: 1036-1039.

Aksornkoae S. \& Tokrishna R. (2003). Overview of shrimp farming and mangrove loss in Thailand. In: Shrimp Farming and Mangrove Loss in Thailand (eds E.B. Barbier and S. Sathirathai). Edward Elgar Publishing Ltd., Northampton, USA.

Alertnet (2010). Indonesia tidal waves displace thousands. <http:/ / www.alertnet.org/thenews/fromthefield/222031/118010664443.htm> (accessed in July 2010)

Alongi, D.M. (2002). Present state and future of the world's mangrove forests. Environmental Conservation 29(3): 331-349.

Alongi, D.M. (2008). Mangrove forests: Resilience, protection from tsunamis, and responses to global climate change. Estuarine, Coastal and Shelf Science 76: 1-13. 
Amarasinghe, U.S., Amarasinghe, M.D. and Nissanka, C. (2002). Investigation of the Negombo estuary (Sri Lanka) brush park fishery, with an emphasis on communitybased management. Fisheries Management and Ecology 9(1): 41-56.

Baird, A. (2006). Myth of green belts. Samudra Report 44: 14-19.

Baird A.H., Campbell S.J., Anggoro A.W., Ardiwijaya R.L., Fadli N., Herdiana Y., Kartawijaya T., Mahyiddin D., Mukminin A., Pardede S.T., Pratchett M.S., Rudi E. \& Siregar A.M. (2005). Acehnese reefs in the wake of the Asian Tsunami. Current Biology 15: 1926-1930.

BAPPENAS (2005). Indonesia: Preliminary Damage and Loss Assessment. The December 26, 2004 Natural Disaster. A Technical Report prepared by BAPPENAS and the International Donor Community. Indonesia National Planning and Development Agency/BAPPENAS, Jakarta Indonesia.

< http://www.crid.or.cr/digitalizacion/pdf/eng/doc16324/doc16324.htm>

Barbier E. \& Cox M. (2002). Economic and demographic factors affecting mangrove loss in the coastal Provinces of Thailand, 1979-1996. Ambio 31(4): 351-357.

Barbier E.B. \& Sathirathai S. (eds) (2003). Shrimp Farming and Mangrove Loss in Thailand. Edward Elgar Publishing Ltd., Northampton, USA.

Bhalla, R.S. (2007). Do bio-shields affect tsunami inundation? Current Science 93(6): 831-833.

Bilham R. (2005). A flying start, then a slow slip. Science 308: 1126-1127.

Borrero J.C. (2005). Field data and satellite imagery of tsunami effects in Banda Aceh. Science 308: 1596

Bowen M.R., Bompard J.M., Andersen I.P., Guizol P. \& Gouyon A. (2000). Anthropogenic fires in Indonesia: a view from Sumatra. In: Forest fires and regional haze in South East Asia (eds Radojevic and Eaton), New York, USA.

<http://www.ssffmp.or.id/ssffmp/file/publication/report/Anthropogenic_Fires_ in_Indonesia.PDF >

BRR (2005a). Aceh and Nias one year after the tsunami. The recovery effort and way forward. A joint report of the BRR and International Partners, December 2005. Rehabilitation and Reconstruction Agency (Badan Rehabilitasi dan Rekonstruksi), Jakarta. < http:/ / www.e-aceh-nias.org/index.php?id=oneyear_main.html >

BRR (2005b). Tsunami Recovery Status Report. As of 8 December 2005. United Nations Information Management Service, Office of the UN Recovery Coordinator for Aceh and Nias in collaboration with the Rehabilitation and Reconstruction Agency (Badan Rehabilitasi dan Rekonstruksi). <http://www.e-aceh-nias.org/index.php?id=indicators_main.html >

Burke L., Selig L. \& Spalding M. (2002). Research Report: Reefs at Risk in Southeast Asia. World Resources Institute, Washington D.C.

< http://marine.wri.org/pubs_description.cfm?PubID=3144 >

Cabreta, M.A., Seijo, J.C., Euano, J. and Perez, E. (1998). Economic values of ecological services from mangrove ecosystem. International Newsletter of Coastal Management 33: 1-2.

Cahoon D.R., Hensel P., Rybczyk J., McLee K.L., Proffitt C.E. \& Perez B.C. (2003). Mass tree mortality leads to mangrove peat collapse at Bay Islands, Honduras, after Hurricane Mitch. Journal of Ecology 91: 1093-1105. 
Chatenoux B. \& Peduzzi P. (2007). Impacts from the 2004 Indian Ocean Tsunami: analysing the potential protecting role of environmental features. Natural Hazards 40(2): 289304.

Chang S.E., Adams B.J., Alder J., Berke P.R., Chuenpagdee R., Ghosh S. \& Wabnitz C. (2006). Coastal ecosystems and tsunami protection after the December 2004 Indian Ocean Tsunami. Earthquake Spectra 22(S3): 863-887.

Cheevaporn V. \& Menasveta P. (2003). Water pollution and habitat degradation in the Gulf of Thailand. Marine Pollution Bulletin 47: 43-51.

Chong H.T., Sasekumar A., Leh M.U.C. \& D'Cruz R. (1990). The fish and prawn communities of a Malaysian coastal mangrove system, with comparisons to adjacent mudflats and inshore waters. Estuarine, Coastal and Shelf Science 31: 703722.

Chou L.M. (1994). Marine environmental issues in Southeast Asia: state and development. Hydrobiologia 285: 139-150.

Chu H.Y., Chen N.C., Yeung M.C., Tam N.F.Y. \& Wong Y.S. (1998). Tide-tank system simulating mangrove wetland for removal of nutrients and heavy metals from wastewater. Water Science and Technology 38(1): 361-368.

Cochard R., Ranamukarhachchi S.L., Shivakoti G., Shipin O., Edwards P.J. \& Seeland, K.T. (2008). The 2004 tsunami in Aceh and Southern Thailand: a review on coastal ecosystems, wave hazards and vulnerability. Perspectives in Plant Ecology, Evolution and Systematics 10: 3-40.

Costanza, R. R., d' Arge, R., de Groot., S., Faber, M., Grasso, B., Hannon, K., Limburg, S., Naeem, R., O'Neill, J., Paruello, R., Raskin, P., Sutton \& van den Belt, M. (1997): The value of the Worlds Ecosystem Services and Natural Capital. Nature 387: 253-260.

Dahdouh-Guebas F., Jayatissa L.P., di Nitto D., Bosire J.O., lo Seen D. \& Koedam N. (2005a). How effective were mangroves as a defence against the recent tsunami? Current Biology 15(12): R443-447

Dahdouh-Guebas F., Hettiarachchi S., Lo Seen D., Batelaan O., Sooriyarachchi S., Jayatissa L.P. \& Koedam N. (2005b). Transitions in ancient inland freshwater resource management in Sri Lanka affect biota and human populations in and around coastal lagoons. Current Biology 15: 579-586.

<http:/ / www.citg.tudelft.nl/live/ binaries/4de0d195-5207-4e67-84bb455c5403ae47/doc/2004DeVos.pdf >

Das, S. \& Vincent, J.R. (2009). Mangroves protected villages and reduced death toll during Indian super cyclone. Proceedings of the National Academy of Sciences of the United States of America 106(18): 7357-7360.

Dierberg F.E. \& Kiattisimkul W. (1996). Issues, impacts, and implications of shrimp aquaculture in Thailand. Environmental Management 20(5): 649-666.

Dorenbosch M., van Riel M.C., Nagelkerken I. \& van der Velde G. (2004). The relationship of reef fish densities to the proximity of mangrove and seagrass nurseries. Estuarine, Coastal and Shelf Science 60: 37-48.

Duarte C.M. (2002). The future of seagrass meadows. Environmental Conservation 29: 192-206. EJF (2006). Mangroves: Nature's defence against Tsunamis - a report on the impact of mangrove loss and shrimp farm development on coastal defences. Environmental Justice Foundation, London, UK. < http://www.ejfoundation.org/pdf/tsunami_report.pdf > 
Ellison J.C. (1999). Impacts of sediment burial on mangroves. Marine Pollution Bulletin 37: 420-426.

Erftemeijer P.L.A. (2002). A new technique for rapid assessment of mangrove degradation: a case study of shrimp farm encroachment in Thailand. Trees 16: 204-208.

FAO (2003). Status and Trends in Mangrove Area Extent Worldwide. Forest Resources Assessment Working Paper 63, prepared by M.L. Wilkie and S. Fortuna. Forestry Department FAO, Rome.< http:/ / www.fao.org// docrep/007/j1533e/j1533e00.htm >

FAO (2005a). In-depth assessment of mangroves and other coastal forests affected by the tsunami in Southern Thailand. THA/05/001. Consultant Report by P. Saenger, International Consultant, November 2005. FAO, Regional Office for Asia and the Pacific, Bangkok.

FAO (2005b). In-depth assessment of mangroves and other coastal forest affected by the tsunami in Southern Thailand. THA/05/001/01/12. Progress Report submitted to the Regional Office for Asia and the Pacific, Food and Agriculture Organisation, Bangkok. Forestry Research Centre, Faculty of Forestry, Kasetsart University, Bangkok.

FAO (2005c). Back-to-Office Report. Backstopping support for the project: "In-depth assessment of mangroves and other coastal forests affected by the tsunami in Southern Thailand. THA/05/001." Reporting officer M. Kashio, Forest Resource Officer, November 2005. FAO, Regional Office for Asia and the Pacific, Bangkok.

FAO (2005d). An assessment of the impacts of the 26th December 2004 earthquake and tsunami on aquaculture in the Provinces of Aceh and North Sumatra, Indonesia. Report prepared by M. Phillips and A. Budhiman. FAO, Indonesia, March 2005. <http://library.enaca.org/NACA-Publications/Tsunami/indonesian-aquacultureassessment-report.pdf $>$

FAO (2005e). Coastal protection and spatial planning in Indonesia. Mission Report by M. Pushparajah, May 2005. Food and Agriculture Organisation, Rome. < http://www.fao.org/forestry/foris/webview/tsunami/index >

FAO-MOAC (2005). Report of Joint FAO/MOAC Detailed Technical Damages and Needs Assessment Mission in Fisheries and Agriculture Sectors in Tsunami Affected Six Provinces in Thailand, 11-24 January 2005. Food and Agriculture Organisation of the United Nations (FAO) in cooperation with Ministry of Agriculture and Cooperatives (MOAC), February 2005.

< http://www.apfic.org/apfic_downloads/tsunami/FAO_MOAC_thai.pdf

Feagin, R.A., Mukherjee, N., Shanker, K., Baird, A.H., Cinner, J., Kerr, A.M., Koedam, N., Sridhar, A., Arthur, R., Jayatissa, L.P., Lo Seen, D., Menon, M., Rodriguez, S., Shamsuddoha, M. \& Dahdouh-Guebas, F. (2010). Shelter from the storm? Use and misuse of coastal vegetation bioshields for managing natural disasters. Conservation Letters 3: 1-11.

Finlayson C.M. (2005). Plant ecology of Australia's tropical floodplain wetlands: a review. Annals of Botany 96: 541-555.

Foster R., Hagan A., Perera N., Gunawan C.A., Silaban I., Yaha Y., Manuputty Y., Hazam I. \& Hodgson G. (2006). Tsunami and Earthquake Damage to Coral Reefs of Aceh, Indonesia. Reef Check Foundation, Pacific Palisades, California. < http:/ / www.reefcheck.org/PDFs/reefcheck_aceh_jan2006_web.pdf > 
Gardner L.R., Michener W.K., Williams T.M., Blood E.R., Kjerve B., Smock L.A., Lipscomb D.J. \& Gresham C. (1992). Disturbance effects of Hurricane Hugo on a pristine coastal landscape: North Inlet, South Carolina, USA. Netherlands Journal of Sea Research 30: 249-263.

GCRMN (2006). Status of Coral Reefs in Tsunami Affected Countries: 2005. Wilkinson C., Souter D. \& Goldberg J. (eds). Global Coral Reef Monitoring Network. Australian Institute of Marine Sciences, Townsville. <http://www.aims.gov.au/pages/research/coralbleaching/scr-tac2005/index.html >

Gedik N., Irtem E. \& Kabdasli S. (2005). Laboratory investigation on tsunami run-up. Ocean Engineering 32: 513-528.

Gelfenbaum G. \& Jaffe B. (2003). Erosion and sedimentation from the 17 July, 1998 Papua New Guinea Tsunami. Pure and Applied Geophysics 160: 1969-1999.

Giesen W. (2004). Causes of Peatswamp Forest Degradation in Berbak NP, Indonesia, and Recommendations for Restoration. Arcadis Euroconsult. International Agricultural Centre(IAC),WageningenUniversity,Netherlands.<http://www.waterfoodecosyste ms.nl/docs/AirHitamLaut/Rehabilitation.PDF >

Green E.P. \& Short F.T. (eds) (2003). World Atlas of Seagrasses. University of California Press, Berkeley.

Gross, M. \& Hoffmann-Riem, H. \& Krohn, W. (2005). Realexperimente. Ökologische Gestaltungsprozesse in der Wissensgesellschaft. Transcript, Bielefeld, Germany.

Gross, M., Hoffmann-Riem, H. (2005). Ecological restoration as a real-world experiment: designing robust implementation strategies in an urban environment. Public Understanding of Science 14(3): 269-284.

Heller V., Unger J \& Hager W. (2005). Tsunami run-up - a hydraulic perspective. Journal of Hydraulic Engineering September: 743-747.

Hoeksema B.W. \& Cleary D.F.R. (2004). The sudden death of a coral reef. Science 303: 1293.

Homcha-Aim, K. (2010). Carbon stocks in biomass and soil of private mangrove plantations (Rhizophora apiculata Bl.) in Yisan Sub-District, Amphawa District, Samut Songkram Province, Thailand. Masters Thesis, Asian Institute of Technology, Bangkok.

Horvitz C.C., Pascarella J.B., McMann S., Freedman A. \& Hofstetter R.H. (1998). Functional roles of invasive non-indigenous plants in hurricane-affected subtropical hardwood forests. Ecological Applications 8(4): 947-974.

Hughes T.P. \& Connell J.H. (1999). Multiple stressors on coral reefs: a long-term perspective. Limnology and Oceanography 44(3): 932-940.

Iftekhar, M.S. (2008). An overview of mangrove management strategies in three South Asian countries: Bangladesh, India and Sri Lanka. International Forestry Review 10(1): 3851.

Ikejima K., Tongnunui P., Medej T. \& Taniuchi T. (2003). Juvenile and small fishes in a mangrove estuary in Trang Province, Thailand: seasonal and habitat differences. Estuarine, Coastal and Shelf Science 56: 447-457.

Islam, M.S. \& Haque, M. (2004). The mangrove-based coastal and near shore fisheries of Bangladesh: ecology, exploitation and management. Reviews in Fish Biology and Fisheries 14: 153-180. 
Islam, M.S. \& Wahab, M.A. (2005): A review on the present status and management of mangrove wetland habitat resources in Bangladesh with emphasis on mangrove fisheries and aquaculture. Hydrobiologia, 542, pp: 165-190.

IUCN (2005c). After the Tsunami: Dealing with Invasive Alien Species. Information Paper No 2. < http://www.iucn.org/tsunami/docs/ip-ias.pdf >

IUCN (2006). Guide to Koh Phra Thong Natural Habitats. Preserving the Ecosystems. IUCN Asia RegionalOffice,Bangkok.DraftReport.<http://www.iucn.org/tsunami/docs/envg uidelines_KPT_final.pdf >

Jaffe B.E., Borrero J.C., Prasetya G.S., Peters R., McAdoo B., Gelfenbaum G., Morton R., Ruggiero P., Higman B., Dengler L., Hidayat R., Kingsley E., Kongko W., Lukijanto, Moore A., Titov V. \& Yulianto E (2006). Northwest Sumatra and offshore islands field survey after the December 2004 Indian Ocean Tsunami. Earthquake Spectra 22(S3): 105-135.

Kanagaratnam, U., Schwarz, A.M., Adhuri, D. \& Dey, M.M. (2006). Mangrove rehabilitation in the West Coast of Aceh - Issues and perspectives. NAGA, Worldfish Center Quarterly 29(3 \& 4): 10-18.

Kerr, A.M., Baird, A.H. (2007). Natural barriers to natural disasters. BioScience 57(2): 102.

Kerr A.M., Baird A.H. \& Campbell S.J. (2006). Comments on "Coastal mangrove forests mitigated tsunami" by K. Kathiresan \& N. Rajendran [Estuar. Coast. Shelf Sci. 65 (2005) 601-606]. Estuarine, Coastal and Shelf Science 67: 539-541.

Koottatep T., Surinkul N., Polprasert C., Kamal A.S.M., Koné D., Montangero A., Heinss U. \& Strauss M. (2005). Treatment of septage in constructed wetlands in tropical climate: lessons learnt from seven years of operation. Water Science and Technology 51(9): 119-126.

Laumonier Y. (1997). The Vegetation and Physiography of Sumatra. Kluwer Academic Publishers, Dordrecht, Netherlands.

Lay T., Kanamori H., Ammon C.J., Nettles M., Ward S.N., Aster R.C., Beck S.L., Bilek S.L., Brudzinski M.R., Butler M.R., DeShon H.R., Ekstrom G., Satake K. \& Sipkin S. (2005). The great Sumatra-Andaman earthquake of 26 December 2004. Science 308: 1127-1133.

Liew, S.C., Gupta, A., Wong, P.P. \& Kwoh, L.K. (2010). Recovery from a large tsunami mapped over time: The Aceh coast, Sumatra. Geomorphology 114: 520-529.

Lugo A.E., Rogers C.S. \& Nixon S.W. (2000). Hurricanes, coral reefs and rainforests: resistance, ruin and recovery in the Carribean. Ambio 29(2): 106-114.

Mather R. (2005). Coral Reef Management and Conservation in Andaman Sea Marine Protected Areas, After the Tsunami. Private Report. <http://www.wwfthai.org/thai/resources/download/AndamanCoralImpactsFea ture.pdf $>$

Mazda, Y., Wolanski, E. \& Ridd, P.V. (Eds.), 2007. The Role of Physical Processes in Mangrove Environments. Manual for the Preservation and Utilization of Mangrove Ecosystems. Terrapub, Tokyo.

McAdoo, B.G., Goff, J.R., Fritz, H.M., Cochard, R. \& Kong, L.S. (2009). The tsunami project: Integrating engineering, natural and social sciences into post-tsunami surveys. American Geophysical Union, Fall Meeting 2009, abstract \#NH34B-01. < http://adsabs.harvard.edu/abs/2009AGUFMNH34B..01M > 
Meilianda, E., Wong P.P., Dohmen-Janssen, C. M., (2006). On the impact of the earthquake and tsunami of 26 December 2004 to the geomorphological settings of the west, north and east coast of Banda Aceh: Report on field work in Banda Aceh, 22 May - 05 June 2005. Civil Engineering \& Management Research Report 2006W-001/WEM-001. Waterbeheer (WEM). Twente University, Netherlands.

<http://www.wem.ctw.utwente.nl/organisatie/Medewerkers/medewerkers/mei lianda/Ella\%20Meilianda/ >

Meltzner A.J., Sieh K., Abrams M., Agnew D.C., Hudnut K.W., Avouac J. \& Natawidjaja D.H. (2006). Uplift and subsidence associated with the great Aceh-Andaman earthquake of 2004. Journal of Geophysical Research 111: B02407, doi:10.1029/2005JB003891.

Moore A., Nishimura Y., Gelfenbaum G., Kamataki T. \& Triyono R. (2006). Sedimentary deposits of the 26 December 2004 tsunami on the northwest coast of Aceh, Indonesia. Earth Planets Space 58: 253-258.

Mumby P.J., Edwards A.J., Arias-Gonzalez J.E., Lindeman K.C., Blackwell P.G., Gall A., Gorczynska M.I., Harborne A.R., Pescod C.L., Renken H., Wabnitz C.C.C. \& Llewellyn G. (2004). Mangroves enhance the biomass of coral reef fish communities in the Carribbean. Nature 427(5): 533-536.

Nalbant S.S., Steacy S., Sieh K., Natawidjaja D. \& McCloskey J. (2005). Earthquake risk on the Sunda trench. Nature 435: 756-757.

Natawidjaja D.H., Sieh K., Chlieh M., Galetzka J., Suwargadi B.W., Cheng H., Edwards R.L., Avouac J. \& Ward S.N. (2006). Source parameters of the great Sumatran megathrust earthquakes of 1797 and 1833 inferred from coral microatolls. Journal of Geophysical Research 111, B06403, doi:10.1029/2005JB004025.

Natawidjaja D.H., Sieh K., Ward S.N., Cheng H., Edwards R.L., Galetzka J. \& Suwargadi B.W. (2004). Paleogeodetic records of seismic and aseismic subduction from central Sumatran microatolls. Journal of Geophysical Research 109, B04306, doi:10.1029 /2003JB002398.

NORDECO (2005). Preliminary assessment on impacts of the tsunami on coastal ecosystems and associated livelihoods in Aceh Province, Indonesia. Global Environment Centre, Wetlands International Indonesia, NORDECO, 10 January 2005.

<http://www.nordeco.dk/nordeco/publications/Preliminary\%20Assessment $\%$ 20on \% 20Impacts $\% 20$ of $\% 20$ Tsunami.pdf >

Parish F. (2005). Press Release: Mangroves might have helped to protect Banda Aceh. Global EnvironmentCentre,Malaysia.

< http://www.riverbasin.org/ev_en.php?ID=3794_201\&ID2=DO_TOPIC >

Pennisi, E., 2005. Powerful tsunami's impact on coral reefs was hit and miss. Science 307: 657.

Pet-Soede C., Cesar H.S.J, Pet J.S. (1999). An economic analysis of blast fishing on Indonesian coral reefs. Environmental Conservation 26: 83-93.

Pomeroy, R.S., Ratner, B.D., Hall, S.J., Pimoljinda, J. \& Vivekanandan, V. (2006). Coping with disaster: rehabilitating coastal livelihoods and communities. Marine Policy 30: 786793.

Ramachandran S., Anitha S., Balamurugan V., Dharanirajan K., Vendhan K.E., Divien M.I.P., Vel A.S., Hussain I.S. \& Udayaraj A. (2005). Ecological impact of tsunami on Nicobar Islands (Camorta, Katchal, Nancowry and Trinkat). Current Science 89(1): 195-200. 
Rama Chandra Prasad, P., Sudhakar Reddy, C, Sundara Rajan, K., Hazan Raza, S. \& Bala Subrahmanya Dutt, C. (2009). Assessment of tsunami and anthropogenic impacts on the forests of the Andaman Islands, India. International Journal of Remote Sensing 30(5): 1235-1249.

ReliefWeb (2006a). OCHA Situation Report No. 1. Floods in Aceh, Indonesia. <http://www.reliefweb.int/rw/RWB.NSF/db900SID/ACIO-6WSH99> (accessed July 2010)

Ridd P.V. (1996). Flow through animal burrows in mangrove swamps. Estuarine, Coastal and Shelf Science 43: 617-625.

Roy S.D. \& Krishnan P. (2005). Mangrove stands of Andamans vis-à-vis tsunami. Current Science 89(11) : 1800-1804.

Sargeant H.J. (2001). Vegetation fires in Sumatra, Indonesia. Oil palm agriculture in the wetlands of Sumatra: destruction or development? European Union Forest Fire Prevention and Control Project with Dinas Kehutanan Propinsi Sumatra Selatan. European Union and Ministry of Forestry, Jakarta, Indonesia.

$<$ http://www.fire.uni-freiburg.de/se_asia/projects/ffpcp/FFPCP-16-Oil-Palm.pdf $>$

Sathirathai, S. \& Barbier, E.B. (2001): Valuing mangrove conservation in Southern Thailand. Contemporary Economic Policy 19(2): 109-122.

Slavich P. (2006). Washing the salt from Aceh's wounds. Ecos 34: 128

< http://www.publish.csiro.au/ecos/index.cfm?sid=10\&issue_id=5214 >

Smith T.J., Boto K.G., Frusher S.D. \& Giddins R.L. (1991). Keystone species and mangrove forest dynamics: the influence of burrowing by crabs on soil nutrient status and forest productivity. Estuarine, Coastal and Shelf Science 33: 419-432.

Soegiarto A. (2004). Research into, and conservation of, mangrove ecosystems in Indonesia. Mangrove Management and Conservation. Present and Future, (ed. M. Vanucci), pp. 5158, United Nations University Press, Tokyo.

Spalding M.D., Balsco F. \& Field C.D. (2001). World Atlas of Coral Reefs. University of California Press, Berkeley.

Stieglitz T., Ridd P. \& Müller P. (2000). Passive irrigation and functional morphology of crustacean burrows in a tropical mangrove swamp. Hydrobiologia 421: 69-76.

Stone, R., 2006. A rescue effort for tsunami-ravaged mangrove forests. Science 314 (5798): 404.

Stott P. (1990). Stability and stress in the savanna forests of mainland South East Asia. Journal of Biogeography 17: 373-383.

Synergy One (2006). Damages map of tsunami affected agricultural areas in Nanggaroe Aceh Darussalam (NAD) Province. Progress Report of Technical Research Collaboration. Synergy One Co., Ltd. Thailand and Indonesian Centre for Agricultural Land Resources Research and Development, Ministry of Agriculture.

Szczucinski W., Niedzielski P., Rachlewicz G., Sobczynski T., Ziola A., Kowalski A., Lorenc S. \& Siepak J. (2005). Contamination of tsunami sediments in a coastal zone inundated by the 26 December 2004 tsunami in Thailand. Environmental Geology 49: 321-331.

Taleb, N.N. (2007). The Black Swan. The Impact of the Highly Improbable. Random House, New York. 
Thampanya U., Vermaat J.E., Sinsakul S. \& Panapitukkul N. (2006). Coastal erosion and mangrove progradation of Southern Thailand. Estuarine, Coastal and Shelf Science 68: 75-85.

Thanawood C., Yongchalermchai C. \& Densrisereekul O. (2006). Effects of the December 2004 tsunami and disaster management in Southern Thailand. Science of Tsunami Hazards 24(3): 206-217.

The Economist (2010). The gulf oil spill: No end in sight. High tempers and low expectations in the Gulf of Mexico. The Economist, June 10th 2010.

< http://www.economist.com/node/16322752 >

(accessed August 2010)

Tomascik T., Mah A.J., Nontji A. \& Moosa M.K. (1997). The Ecology of the Indonesian Seas. Periplus Editions (HK) Ltd., Singapore.

UNDP (2006). Malaysia's Peat Swamp Forests. Conservation and Sustainable Use. United Nations Development Programme, Kuala Lumpur, Malaysia.

UNEP (2004). Seagrasses in the South China Sea. UNEP/GEF/SCS, Technical Publication No. 3. United Nations Environment Programme, Nairobi.

<http://www.unepscs.org/Publication/Booklets/Seagrass \%20booklet\%20combin e\%20version.pdf $>$

UNEP (2005a). After the Tsunami: Rapid Environmental Assessment. United Nations Environment Programme, Nairobi.

< http://www.unep.org/tsunami/reports/TSUNAMI_report_complete.pdf >

UNEP-WCMC (2006). In the frontline: shoreline protection and other ecosystem services from mangroves and coral reefs. UNEP-WCMC, Cambridge.

< http://www.unep.org/pdf/infrontline_06.pdf >

USGS (2005). USGS Scientists in Sumatra Studying Recent Tsunamis. U.S. Geological Survey. Field Reports by the The West Sumatra International Tsunami Survey Team (ITST). < http://walrus.wr.usgs.gov/news/reportsleg1.html > (accessed in July 2010)

Whitten T., Damanik S.J., Anwar J. \& Hisyam N. (1997). The Ecology of Sumatra. Periplus.

Wibisono, I.T.C. \& Suryadiputra, I.N.N. (2006). Study of lessons learned from mangrove/coastal ecosystem restoration efforts in Aceh since the tsunami. Wetlands International Indonesia Programme. Bogor, Indonesia.

WIIP (2005). Tsunami of Aceh and North Sumatra, 26 December 2004. Report by Wetlands International - Indonesia Programme.

$<$ http://www.wetlands.org/Tsunami/data/TSUNAMI-INDONESIAWIIP,English.doc >

Wikipedia(2010). <http:/ / en.wikipedia.org/wiki/Humanitarian_response_to_the_2004_Indian_Oce an_earthquake > (accessed in July 2010)

Wong P.P. (2003). Where have all the beaches gone? Coastal erosion in the tropics. Singapore Journal of Tropical Geography 24(1): 111-132.

Wong Y.S., Lan C.Y., Chen G.Z., Li S.H., Chen X.R. Liu Z.P. \& Tam N.F.Y. (1995). Effect of wastewater discharge on nutrient contamination of mangrove soils and plants. Hydrobiologia 295: 243-254. 
Wong Y.S., Tam N.F.Y. \& Lan C.Y. (1997). Mangrove wetlands as wastewater treatment facility: a field trial. Hydrobiologia 352: 49-59.

Young E. (2005). Crop revival for Aceh after the tsunami. New Scientist 187(2514): 9 


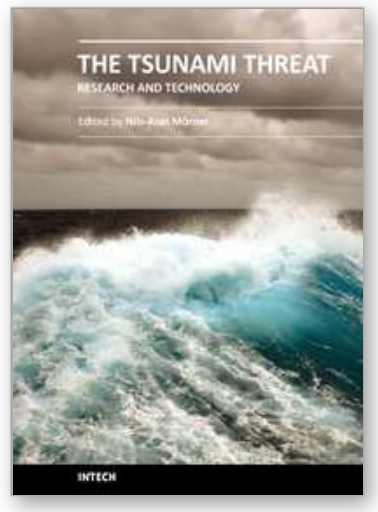

\author{
The Tsunami Threat - Research and Technology \\ Edited by Nils-Axel MÃ
}

ISBN 978-953-307-552-5

Hard cover, 714 pages

Publisher InTech

Published online 29, January, 2011

Published in print edition January, 2011

Submarine earthquakes, submarine slides and impacts may set large water volumes in motion characterized by very long wavelengths and a very high speed of lateral displacement, when reaching shallower water the wave breaks in over land - often with disastrous effects. This natural phenomenon is known as a tsunami event. By December 26, 2004, an event in the Indian Ocean, this word suddenly became known to the public. The effects were indeed disastrous and 227,898 people were killed. Tsunami events are a natural part of the Earth's geophysical system. There have been numerous events in the past and they will continue to be a threat to humanity; even more so today, when the coastal zone is occupied by so much more human activity and many more people. Therefore, tsunamis pose a very serious threat to humanity. The only way for us to face this threat is by increased knowledge so that we can meet future events by efficient warning systems and aid organizations. This book offers extensive and new information on tsunamis; their origin, history, effects, monitoring, hazards assessment and proposed handling with respect to precaution. Only through knowledge do we know how to behave in a wise manner. This book should be a well of tsunami knowledge for a long time, we hope.

\title{
How to reference
}

In order to correctly reference this scholarly work, feel free to copy and paste the following:

Roland Cochard (2011). The 2004 Tsunami in Aceh and Southern Thailand: Coastal Ecosystem Services, Damages and Resilience, The Tsunami Threat - Research and Technology, Nils-Axel MÃ rrner (Ed.), ISBN: 978-953-307-552-5, InTech, Available from: http://www.intechopen.com/books/the-tsunami-threat-researchand-technology/the-2004-tsunami-in-aceh-a-southern-thailand-coastal-ecosystem-services-damages-andresilience

\section{INTECH}

open science | open minds

\author{
InTech Europe \\ University Campus STeP Ri \\ Slavka Krautzeka 83/A \\ 51000 Rijeka, Croatia \\ Phone: +385 (51) 770447 \\ Fax: +385 (51) 686166 \\ www.intechopen.com
}

\author{
InTech China \\ Unit 405, Office Block, Hotel Equatorial Shanghai \\ No.65, Yan An Road (West), Shanghai, 200040, China \\ 中国上海市延安西路65号上海国际贵都大饭店办公楼 405 单元 \\ Phone: +86-21-62489820 \\ Fax: +86-21-62489821
}


(C) 2011 The Author(s). Licensee IntechOpen. This chapter is distributed under the terms of the Creative Commons Attribution-NonCommercialShareAlike-3.0 License, which permits use, distribution and reproduction for non-commercial purposes, provided the original is properly cited and derivative works building on this content are distributed under the same license. 